\title{
Four yeast spliceosomal proteins (PRP5, PRP9, PRP11, and PRP21) interact to promote $\mathrm{U} 2$ snRNP binding to pre-mRNA
}

\author{
S.W. Ruby, ${ }^{1,4}$ T.-H. Chang, ${ }^{2}$ and J. Abelson ${ }^{3}$ \\ ${ }^{1}$ Department of Cell Biology, University of New Mexico, School of Medicine and Cancer Center, Albuquerque, New Mexico \\ 87131 USA; ${ }^{2}$ Department of Molecular Genetics, Ohio State University, Columbus, Ohio 43210 USA; ${ }^{3}$ Division of \\ Biology 147-75, California Institute of Technology, Pasadena, California 91125 USA
}

\begin{abstract}
We have analyzed the functions of several pre-mRNA processing (PRP) proteins in yeast spliceosome formation. Here, we show that PRP5 (a DEAD box helicase-like protein), PRP9, and PRP11 are each required for the U2 snRNP to bind to the pre-spliceosome during spliceosome assembly in vitro. Genetic analyses of their functions suggest that they and another protein, PRP21, act concertedly and/or interact physically with each other and with the stem-loop IIa of U2 snRNA to bind U2 snRNP to the pre-mRNA. Biochemical complementation experiments also indicate that the PRP9 and PRP11 proteins interact. The PRP9 and PRP11 proteins may be functioning similarly in yeast and mammalian cells. The requirement for ATP and the helicase-like PRP5 protein suggests that these factors might promote a conformational change (involving either the U1 or U2 snRNP) that is required for the association of U2 snRNP with the pre-mRNA.
\end{abstract}

[Key Words: Splicing; pre-mRNA; spliceosome; U2 snRNP; PRP proteins]

Received June 28, 1993; revised version accepted August 9, 1993.

A key to understanding the mechanism and regulation of nuclear precursor messenger RNA (pre-mRNA) splicing lies in discovering the functions of numerous trans-acting factors. These factors can be grouped into two classes: the small nuclear ribonucleoprotein particles (snRNPs)-U1, U2, U4/U6, and U5-and a multitude of non-snRNP factors (for review, see Green 1991; Guthrie 1991; Ruby and Abelson 1991; Brown et al. 1992; Rymond and Rosbash 1992; Moore et al. 1993). The snRNPs and some non-snRNP factors assemble on the premRNA to form the spliceosome on which splicing occurs. U1 snRNP binds first to the pre-mRNA, followed by the U2 snRNP and, finally, by the tri-snRNP U4/U5/ U6 particle. Some non-snRNP factors may become integral components of the spliceosome, whereas others may only loosely or transiently associate with the snRNPs and/or the spliceosome. The functions of these non-snRNP factors are particularly intriguing as their elucidation may lead to our understanding of why the premRNA splicing apparatus is so complex and requires ATP.

Pre-mRNA splicing occurs in two transesterification reactions, which are mechanistically the same as those of the group II self-splicing introns (for discussion, see

${ }^{4}$ Corresponding author.
Weiner 1993). As the group II selfsplicing introns require no nucleotide or protein cofactors in vitro (for review, see Jacquier 1990|, it is thought that pre-mRNA splicing is likely to be catalyzed by RNA as well. The spliceosomal small nuclear RNAs (snRNAs) may have this function. Thus, it is a quandary as to the functions of the numerous snRNP and non-snRNP proteins in premRNA splicing. Some non-snRNP factors such as the mammalian ASF/SF2 (Ge et al. 1991; Krainer et al. 1991) and SC35 (Fu and Maniatis 1992), and the Drosophila transformer (Tra), Tra2 (Tian and Maniatis 1992), and sex-lethal (Sxl) (Baker 1989) proteins function in the recognition and selection of introns and splice sites. One non-snRNP protein has been proposed to regulate the fidelity of splicing (Burgess et al. 1990).

Nearly 40 proteins involved in splicing have been identified genetically in the yeast Saccharomyces cerevisiae (for review, see Guthrie 1991; Ruby and Abelson 1991; Brown et al. 1992; Rymond and Rosbash 1992). Over 20 of these proteins have been found in screens for temperature-sensitive (ts) pre-RNA processing $(p r p)$ mutants defective in pre-mRNA splicing. Among the genes sequenced so far, five-PRP2, PRP5, PRP16, PRP22, and $P R P 28$ - have deduced amino acid sequences resembling known ATP-dependent RNA helicases (for review, see Schmid and Linder 1992; Wassarman and Steitz 1992). None of these five PRP proteins has yet been shown to 
have RNA unwinding activity, but two have been shown to have RNA-dependent ATPase activity (Schwer and Guthrie 1991; Kim and Lin 1993). It is thought that these putative helicases could unwind secondary structures during splicing or that they could catalyze a more subtle ATP-dependent RNA conformational change. Several base-pairing interactions form between snRNAs (Hausner et al. 1990; Datta and Weiner 1991; Wu and Manley 1991; Madhani and Guthrie 1992; McPheeters and Abelson 1992; and references therein) or between an snRNA and the pre-mRNA (Newman and Norman 1992; Reich et al. 1992; Sawa and Abelson 1992; Wassarman and Steitz 1992; Wyatt et al. 1992; and references therein). Other base-pairings such as that between the U4 and U6 snRNAs may separate during spliceosome assembly (Cheng and Abelson 1987; Lamond et al. 1988). Such dynamic interactions may explain some of the functions of ATP and the putative helicases.

Many PRP proteins have been shown to be required for spliceosome assembly (Ruby and Abelson 1991; Brown et al. 1992; Rymond and Rosbash 1992; Moore et al. 1993). To understand the functional relationship of some of these proteins, we used a genetic approach to identify proteins that may interact physically or functionally with one another. By a combination of genetic and biochemical assays we have found that four proteins, PRP5, PRP9, PRP11, and PRP21, probably interact physically and/or act concertedly to promote U2 snRNP binding to the pre-mRNA during spliceosome assembly.

\section{Results}

\section{Interactions among PRP genes}

We used two in vivo genetic tests to look for potentially interacting proteins. First, we analyzed the phenotypes of haploids with various combinations of two temperature-sensitive prp mutations. Second, we tested the activities of several wild-type $P R P$ genes in suppressing temperature-sensitive mutations in other $P R P$ genes. In the first test, if two proteins act sequentially and/or independently in the same pathway, mutations in their genes may show an epistatic relationship; that is, in a haploid double mutant, the phenotype from only one mutation may be observed (Jarvick and Botstein 1973). If the proteins act concertedly, are interacting physically, or are present in the same complex, mutations in their genes may act epistatically, additively, or synergistically (Huffaker et al. 1987). When synergistic interactions occur, the haploid double mutants can be inviable at or extremely sensitive to even the permissive temperature $\left(23-26^{\circ} \mathrm{C}\right)$.

We analyzed the phenotypes of numerous haploid double mutants. To minimize nonspecific effects resulting from unrelated variations in strain genetic backgrounds, we created a set of nearly isogenic haploid strains by repeatedly backcrossing the strains into a single wildtype strain. These haploid temperature-sensitive mutants were then crossed with each other. The resulting heterozygous diploids were sporulated, and the meiotic progeny were germinated at $23^{\circ} \mathrm{C}$. The temperature sensitivities of the progeny were determined by replica-plating tests at $26^{\circ} \mathrm{C}, 30^{\circ} \mathrm{C}, 34^{\circ} \mathrm{C}$, and $37^{\circ} \mathrm{C}$. Most of the crosses gave good spore viability with only a few notable exceptions: the prp3-1 mutation combined with prp4-1; prp4-1 with prp24-1; and various combinations of prp5-1, prp5-3, prp9-1, prp9-2, prp11-1, and prp21-1 mutations (Tables 1 and 2). In these crosses we observed that about one-fourth of the meiotic progeny were inviable or extremely temperature-sensitive. Most of the inviable meiotic progeny germinated and underwent one to several divisions before dying. Complementation analyses were performed on all viable meiotic products of these crosses to confirm the genotypes as well as to deduce the genotypes of the inviable progeny. Whereas most haploid single mutants grew at or below $30^{\circ} \mathrm{C}$, the haploid double mutants were dead at either $23^{\circ} \mathrm{C}$ or $26^{\circ} \mathrm{C}$ (Tables 1 and 2). We were particularly interested in the combinations involving the prp5, prp9, prp11, and prp21 mutations as the pattern of synergistic interactions suggested that the respective wild-type proteins act at the same step of spliceosome assembly.

While performing these crosses we observed that the $P R P 9$ and $P R P 11$ genes are linked (data not shown). To study the interactions between these two genes, we constructed a diploid strain homozygous for a prp 9 mutation and heterozygous for a HIS3-disrupted prp11 null mutation. Next, we introduced either the wild-type or mutant allele of $P R P 11$ (on a centromeric, URA3-marked plasmid) into the diploids. We then determined the genotypes and phenotypes of the meiotic progeny by replicaplating tests. With the wild-type $P R P 11$ gene, $\mathrm{Ura}^{+} \mathrm{His}^{+}$ meiotic progeny can be obtained (Table 3 ). With the mutant prp11-1 allele the $\mathrm{Ura}^{+} \mathrm{His}^{+}$(prp9-1 prp11-1 and prp9-2 prp11-1 double mutant) progeny germinate and then die. Thus, either the prp9-1 or prp9-2 mutation acts synergistically with the prp11-1 mutation.

We also examined the interactions between several prp mutations and two mutations in the SNR20 gene encoding the U2 snRNA (Fig. 1). Either the G53A or C62U mutation in stem-loop IIa of the U2 snRNA confers cold sensitivity (Ares and Igel 1990), alters the structure of the U2 snRNA in vivo, and prevents the U2 snRNP from binding to the pre-spliceosome complex (Zavanelli and Ares 1991). The experimental design for mating the appropriate strains and analyzing their progeny is diagramed in Figure 1B. All haploid meiotic progeny with the prp 9 , prp11, or prp21 mutation and either the G53A or C62U mutation died after germination (Fig. $1 \mathrm{~B}, \mathrm{C})$. We obtained progeny with a prp mutation only if they also carried wild-type U2 snRNA. In contrast, in crosses with either the prp3 or prp 4 mutant, we readily obtained prp mutant progeny carrying either a wild-type or mutant U2. In this analysis, we also found that the SNR20 and PRP5 genes are linked (Experiment 1, Fig. $1 C)$. To study the interaction between these two genes in vivo, we modified the experimental approach slightly (see Materials and methods). We found that PRP5 meiotic progeny with either a wild-type or mutant U2 are viable, whereas prp5-1 progeny with a mutant $\mathrm{U} 2$ are 


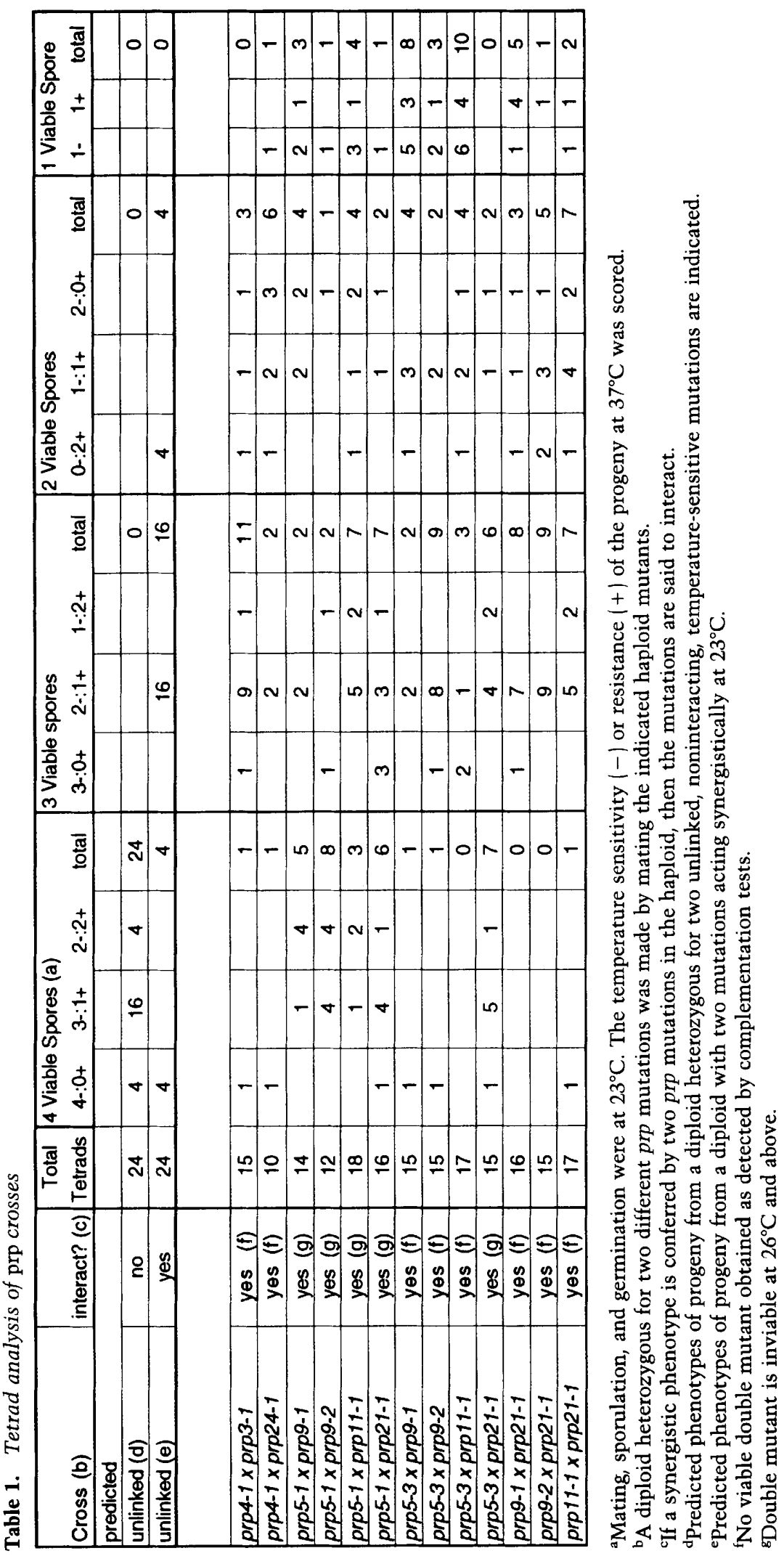


Ruby et al.

Table 2. Growth of haploid double mutants

\begin{tabular}{|c|c|c|c|c|c|c|c|c|c|}
\hline & $\operatorname{prp4-1}^{\mathrm{a}}$ & prp5-1 & prp5-3 & prp6-1 & prp9-1 & prp9-2 & prp11-1 & $\begin{array}{c}s n r 20 \\
\text { U2-G53A }\end{array}$ & $\begin{array}{c}s n r 20 \\
\text { U2-C62U }\end{array}$ \\
\hline prp2-1 & + & + & $n t$ & + & + & + & $\mathrm{nt}$ & $n t$ & $n t$ \\
\hline prp3-1 & -23 & $n t$ & + & + & $n t$ & + & + & + & + \\
\hline prp4-1 & & + & + & + & + & + & + & + & + \\
\hline prp5-1 & + & & & + & -26 & -26 & -26 & -23 & -23 \\
\hline prp5-3 & + & & $\%$ & + & -23 & -23 & -23 & $n t$ & $n t$ \\
\hline prp6-1 & + & + & + & & + & + & + & $n t$ & $n t$ \\
\hline prp6-3 & + & $\mathrm{nt}$ & $n t$ & & + & + & + & $n t$ & $n t$ \\
\hline prp8-1 & + & + & $n t$ & + & + & + & + & $n t$ & $n t$ \\
\hline prp9-1 & + & & & + & & & -23 & -23 & -23 \\
\hline prp9-2 & + & & & + & & & -23 & -23 & -23 \\
\hline prp11-1 & + & $\%$ & $\%$ & + & & 桨 & 6, & -23 & -23 \\
\hline prp16-2 & + & + & + & + & + & $\mathrm{nt}$ & + & $n t$ & $n t$ \\
\hline prp17-1 & + & + & + & + & + & + & + & $\mathrm{nt}$ & $\mathrm{nt}$ \\
\hline prp18-1 & + & $n t$ & + & + & + & + & + & $n t$ & $n t$ \\
\hline prp19-1 & + & + & + & + & + & + & + & $n t$ & $n t$ \\
\hline prp20-1 & + & + & + & + & + & $\mathrm{nt}$ & + & $n t$ & $n t$ \\
\hline prp21-1 & + & -26 & -26 & + & -23 & -23 & -23 & -23 & -23 \\
\hline prp22-1 & + & + & + & + & + & + & + & $n t$ & $n t$ \\
\hline prp24-1 & -23 & + & + & + & + & + & + & $n t$ & $n t$ \\
\hline prp27-1 & + & + & + & + & + & + & + & $n t$ & $n t$ \\
\hline
\end{tabular}

$\left(+\mid\right.$ Double mutant is viable $;(-23)$ double mutant is inviable at $23^{\circ} \mathrm{C} ;(-26)$ double mutant is inviable at $26^{\circ} \mathrm{C}$; (nt) not tested. ${ }^{\text {a }}$ prp mutations are temperature sensitive. A diploid heterozygous for two different prp mutations was made by mating the indicated haploid mutants. Mating, sporulation, and germination were at $23^{\circ} \mathrm{C}$. The temperature-sensitive phenotypes of the progeny and the number of ditypes $(4-: 0+$ and $2-: 2+)$ and tetratypes $(3-: 1+)$ from at least 10 tetrads for each cross were scored. (Data available upon request.) The viabilities of the haploid double mutants at the permissive temperature are indicated.

${ }^{b}$ SNR20 encodes the U2 snRNA; G53A and C62U mutations are cold sensitive.

inviable (Experiment 2, Fig. 1C). These patterns of lethality suggest that the PRP5, PRP9, PRP11, and PRP21 proteins act concertedly or interact physically with the U2 snRNA.

We used a second type of genetic test, multicopy suppression, to examine the interaction between the $P R P$ genes. Increasing the copy number of one gene may suppress a conditional mutation in its interacting partner gene. We introduced wild-type copies of the PRP5, PRP9, or PRP11 genes into various haploid prp mutant strains and assayed the temperature sensitivities of the transformed strains. The genes were introduced on either lowcopy, centromeric, or high-copy vectors. Although we never observed complete suppression of the temperature sensitivity, we did find that a high-copy number of the $P R P 9$ gene can partially suppress the temperature sensitivity of the prp5-1, prp11-1, or prp21-1 mutant at $30^{\circ} \mathrm{C}$ or $34^{\circ} \mathrm{C}$, temperatures at which these mutants grow

Table 3. Interactions between prp 9 and prp11 mutations

\begin{tabular}{|c|c|c|c|}
\hline Genotype of diploid & $\begin{array}{l}\text { Gene on } \\
U R A 3-\text { plasmid }\end{array}$ & $\begin{array}{l}\text { Number of tetrads } \\
\text { with temperature- } \\
\text { sensitive, His }{ }^{+} \\
\text {Ura }^{+} \text {spore }\end{array}$ & $\begin{array}{l}\text { Total number } \\
\text { of tetrads }\end{array}$ \\
\hline \multirow{2}{*}{ prp9-1/prp9-1, PRP11/prp11::HIS3 } & PRP11 & 10 & 15 \\
\hline & prp11-1 & 0 & 13 \\
\hline \multirow[t]{2}{*}{ prp9-2/prp9-2, PRP11/prp11::HIS3 } & PRP11 & 7 & 14 \\
\hline & prp11-1 & 0 & 16 \\
\hline
\end{tabular}




\section{A}

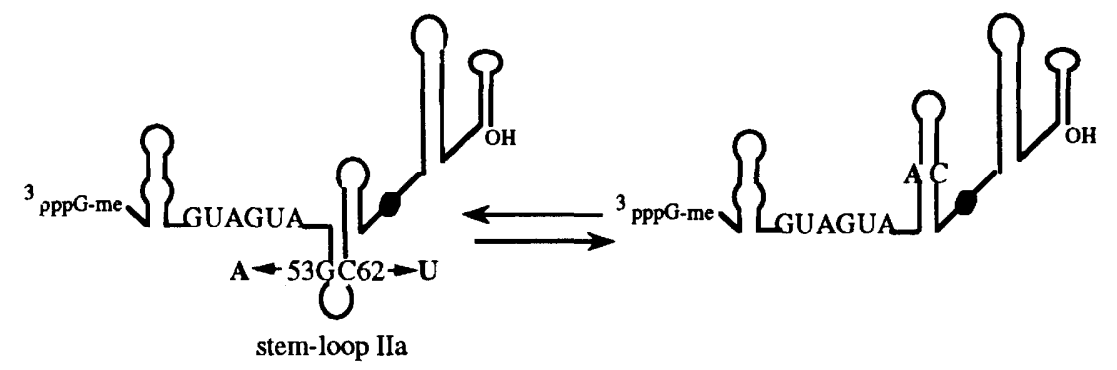

B

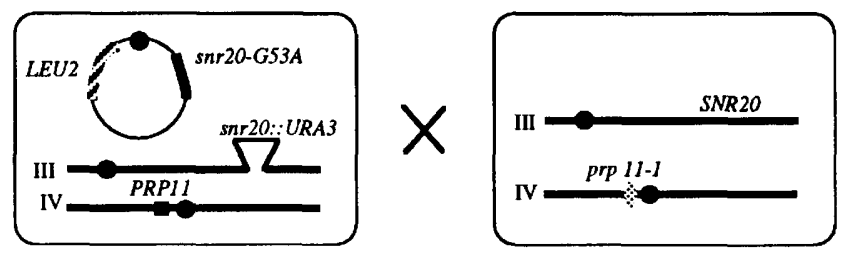

sporulate diploid

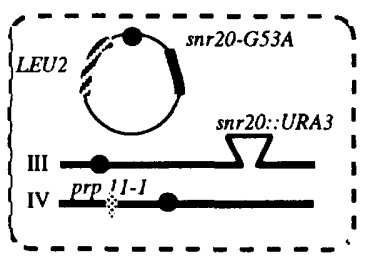

Inviable

Urat

Leut)

C

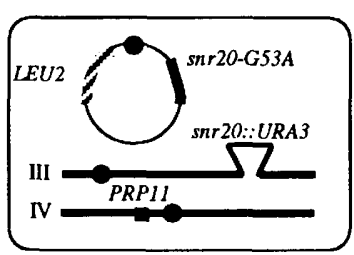

cs

Urat

Leut

\begin{tabular}{|c|c|c|c|}
\hline \multicolumn{2}{|c|}{ genotype of heterozygous diploid } & \multicolumn{2}{|c|}{ number of tetrads } \\
\hline prp $\quad \mathrm{X}$ & $\begin{array}{c}\text { SNR20 } \\
\text { (U2 SnRNA) }\end{array}$ & $\begin{array}{l}\text { with ts, Leut } \\
\text { Ura+ spore }\end{array}$ & total \\
\hline prp3-1 & $\begin{array}{l}w t \\
G 53 A \\
\text { C62U }\end{array}$ & $\begin{array}{l}10 \\
8 \\
7\end{array}$ & $\begin{array}{l}15 \\
13 \\
12\end{array}$ \\
\hline prp4-1 & $\begin{array}{c}w t \\
G 53 A \\
C 62 U\end{array}$ & $\begin{array}{l}7 \\
6 \\
4\end{array}$ & $\begin{array}{l}14 \\
16 \\
14 \\
\end{array}$ \\
\hline $\begin{array}{l}\text { prp5-1 } \\
\text { (Experiment 1) }\end{array}$ & $\begin{array}{l}w t \\
G 53 A \\
C 62 U\end{array}$ & $\begin{array}{l}0 \text { (linked) } \\
0 \text { (linked } \\
0 \text { (linked) }\end{array}$ & $\begin{array}{l}15 \\
13 \\
12\end{array}$ \\
\hline $\begin{array}{l}\text { prp5 }-1 \\
\text { (Experiment 2) }\end{array}$ & $\begin{array}{c}w t \\
G 53 A \\
C 62 U\end{array}$ & $\begin{array}{l}8 \\
8 \\
\end{array}$ & $\begin{array}{l}16 \\
13 \\
11 \\
\end{array}$ \\
\hline prp9-1 & $\begin{array}{c}w t \\
G 53 A \\
C 62 U\end{array}$ & $\begin{array}{l}7 \\
0 \\
0 \\
0 .\end{array}$ & $\begin{array}{l}14 \\
13 \\
14\end{array}$ \\
\hline prp $9-2$ & $\begin{array}{c}w t \\
G 53 A \\
C 62 U\end{array}$ & $\begin{array}{l}7 \\
0 \\
0 \\
0\end{array}$ & $\begin{array}{l}14 \\
15 \\
14\end{array}$ \\
\hline prpl1-1 & $\begin{array}{l}\text { Gt } \\
\text { C62U }\end{array}$ & $\begin{array}{l}6 \\
0 \\
0\end{array}$ & $\begin{array}{l}13 \\
12 \\
13\end{array}$ \\
\hline prp21-1 & $\begin{array}{l}w t \\
G 53 A \\
\text { C62U }\end{array}$ & $\begin{array}{l}7 \\
0 \\
0 \\
\end{array}$ & $\begin{array}{l}16 \\
15 \\
12\end{array}$ \\
\hline
\end{tabular}

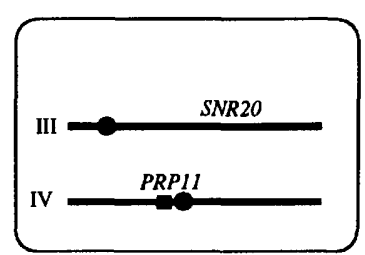

wt

Figure 1. Interactions between prp and U2 snRNA mutations. $(A)$ The positions of the two cold-sensitive mutations G53A and C62U in the U2 snRNA are indicated. Either mutation alters the distribution of the two forms of U2 snRNA in vivo as shown for the G53A mutation, so that the form on the right is at higher concentrations in the G53A mutant (Zavanelli and Ares 1989). (B) The experimental protocol used to test interactions between a prp mutation and the G53A or C62U U2 snRNA mutation is diagramed here. The U2 snRNA is encoded by the SNR20 gene. One haploid strain has an snr20::URA3 disruption mutation and contains a $L E U 2$-marked plasmid with the mutant (G53A or C62U), or wild-type SNR20 gene. The other haploid has a prp mutation. These two strains are mated, and the resulting meiotic progeny are analyzed by replicaplating tests. Here, we show the expected results if there is an interaction between the snr20-G53A and prp11-1 mutations: no temperature-sensitive, $\mathrm{Ura}^{+}{ }^{+} \mathrm{Leu} 2^{+}$progeny will be viable. $(C)$ The numbers of progeny with the relevant phenotypes are indicated. The results are also summarized in Table 2. The PRP5 and SNR20 genes were found to be linked in Experiment 1. Additional strains were constructed to test the interactions between these two genes /see Materials and methods) and the results of Experiment 2 are given. 
poorly or not at all (Fig. 2). The suppression of the prp21-1 mutation is particularly striking; even a slight increase in copy number of $P R P 9$ can partially suppress the prp21-1 mutation. PRP11 also can partially suppress the prp9-1, prp9-2, and prp21-1 mutations at $30^{\circ} \mathrm{C}$. Conversely, multiple copies of $P R P 11$ cannot suppress a prp 9 null mutation. To show this we constructed a diploid heterozygous for a HIS3-disrupted prp9 null mutation and transformed the diploid with a URA3-marked plasmid with either the wild-type $P R P 9$ or $P R P 11$ gene. Subsequently, we obtained 13 of 16 , or 0 of 16 tetrads respectively, with $\mathrm{His}^{+} \mathrm{Ura}^{+}$progeny. These results indicate that $P R P 11$ is not functionally replacing $P R P 9$.

\section{In vitro heat inactivation and complementation of a prp9 mutant extract}

We then analyzed the functions of the PRP5, PRP9, and PRP11 proteins by biochemical assays. [The in vitro analysis of the PRP21 protein is reported elsewhere (Arenas and Abelson 1993).] One approach to dissecting the function of a protein is to study the in vitro phenotype conferred by temperature-sensitive mutations. Splicing extracts from several temperature-sensitive prp mutants are temperature-sensitive in vitro. However, extract from the prp9-1 mutant is not temperature-sensitive in vitro under the conditions used previously (Lustig et al. 1986). We therefore sought in vitro conditions to specifically inactivate $p r p 9$ extract.

We made active splicing extract from the prp9-1 mutant grown at the permissive temperature and then found two sets of conditions for inactivating the extract in vitro. In one set, the extract is briefly incubated in a low concentration of $\mathrm{MgCl}_{2}$ at $38^{\circ} \mathrm{C}$ prior to the splicing assay. The short heat treatments inactivate the prp9 extract and other prp mutant extracts but not control extracts such as that of the prp9-1 revertant, prp9R1 (Fig. 3 ). The second set of inactivating conditions is to incubate the splicing reactions at $30^{\circ} \mathrm{C}$ instead of the normal $23^{\circ} \mathrm{C}$. At this temperature, the prp 9 extract does not splice pre-mRNAs, whereas the control extracts are active (data not shown). Incubation at $30^{\circ} \mathrm{C}$, however, may not be sufficient to inactivate the extract for subsequent splicing at lower temperatures. The prp9 extract with splicing buffer components but without ATP and premRNA, is resistant to prolonged incubations at $30^{\circ} \mathrm{C}$ when subsequently assayed for splicing activity at $23^{\circ} \mathrm{C}$ (data not shown; see also Lustig et al. 1986). The roles of ATP and pre-mRNA in inactivating the extract at $30^{\circ} \mathrm{C}$ were not investigated further.
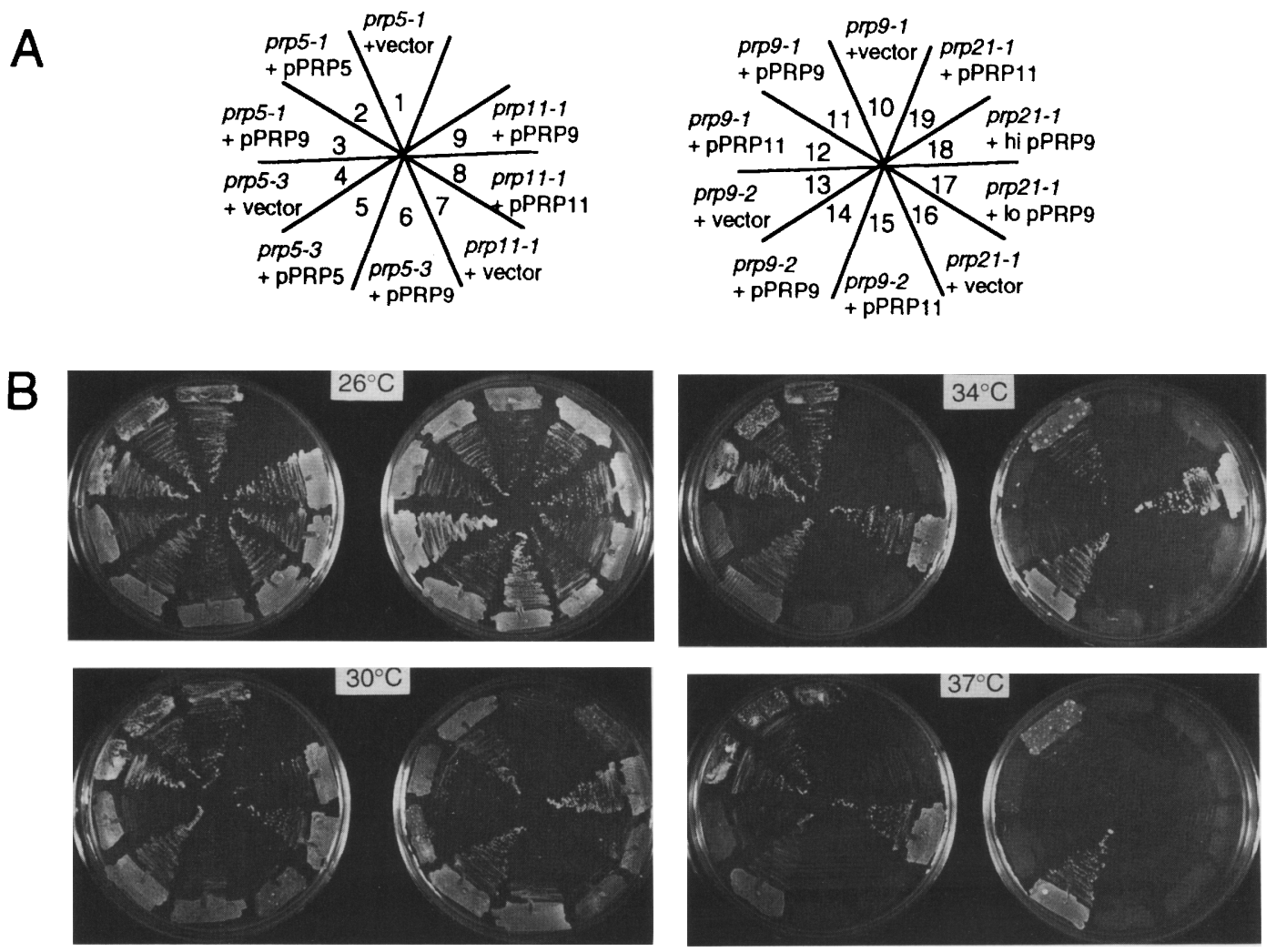

Figure 2. Multicopy suppression of temperature-sensitive prp mutations. $(A)$ Temperature-sensitive mutant prp strains (indicated in italics) were transformed with either a vector plasmid, or high-copy plasmids with the wild-type $P R P 5, P R P 9$, or $P R P 11$ genes (indicated by pPRP), or a low-copy plasmid with the PRP9 gene (indicated lo-pPRP9). (B) Equal numbers of cells of the transformants were plated in the sectors of selective medium. The transformants with a partially suppressed temperature-sensitive phenotype and the prp5-3 transformants with no such phenotype are shown here. 


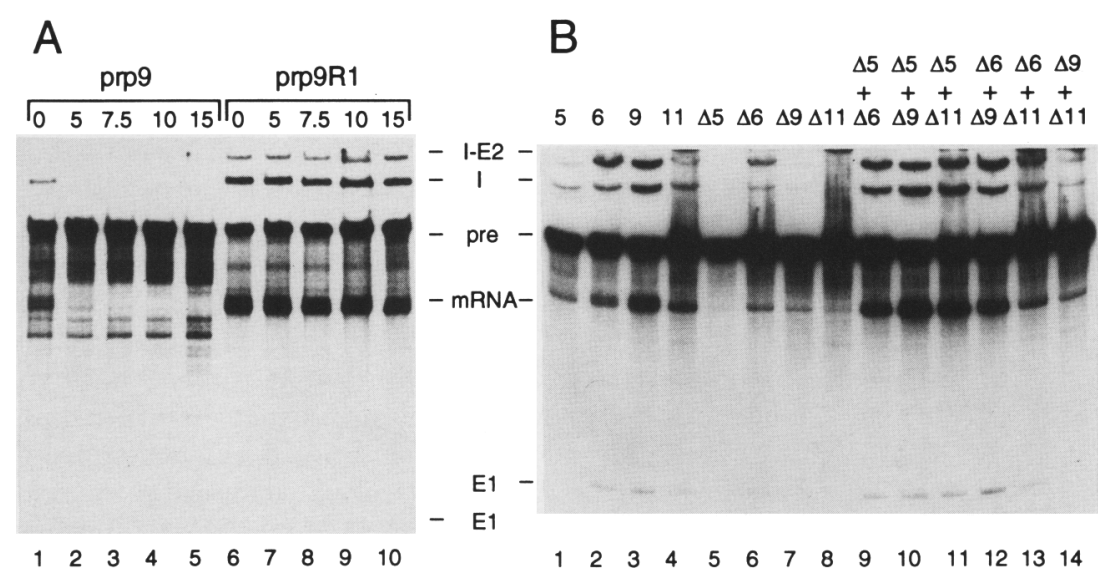

Figure 3. In vitro inactivation and complementation of heat-inactivated extracts. $(A)$ Active whole-cell splicing extracts from the prp9-1 mutant or prp $9 R 1$ revertant were incubated in vitro at $38^{\circ} \mathrm{C}$ for the times indicated. The splicing assays were then initiated by the addition of splicing buffer components, ATP, and radiolabeled pre-mRNA and incubated for $30 \mathrm{~min}$ at $23^{\circ} \mathrm{C}$. The pre-mRNA (pre), splicing intermediates [intron-exon 2 (I-E2) and free exon 1 (E1)], and splicing products [mRNA and lariat intron (I)] were extracted, analyzed by denaturing gel electrophoresis, and visualized by autoradiography as shown here. $(B)$ Active splicing extracts from mutants prp5-1, prp6-1, prp9-1, and prp11-1 (lanes 1-4) were heat inactivated in vitro $(\Delta 5, \Delta 6, \Delta 9, \Delta 11$; lanes $5-8)$. The inactivated extracts were then mixed pairwise in various combinations (lanes 9-14). Splicing assays were initiated by the addition of splicing buffer components, ATP, and radiolabeled pre-mRNA and incubated for $30 \mathrm{~min}$ at $23^{\circ} \mathrm{C}$. The RNAs were analyzed as in $A$.

To determine that the in vitro temperature sensitivity is attributable to the temperature-sensitive prp 9 mutation and not to nonspecific inactivation of splicing components, we analyzed the effects of the mutation in two ways. First, we determined whether the heat-inactivated prp 9 extract could complement inactivated extracts from other mutants. If a distinct component is inactivated in each extract, then different extracts should complement one another. If the components are not exchangeable, then the extracts will fail to complement. Extracts from prp5-1, prp6-1, prp9-1, and prp11-1 mutants were individually heat inactivated and then mixed pairwise and assayed for splicing activity at $23^{\circ} \mathrm{C}$ (Fig. $3 \mathrm{~B}$ ). Each inactivated extract alone has little or no splicing activity but can complement at least two other extracts. Often such complementation results in recovering more splicing activity than is present in single extracts prior to heat inactivation. One combination of extracts (prp9 and prp11) consistently complement poorly or not at all. This failure could be attributable to either nonspecifically inactivating splicing components or specifially inactivating a nondissociable complex containing the mutant protein.

To test further that the in vitro temperature-sensitive phenotype is attributable specifically to the temperature-sensitive mutation, we isolated revertants of the prp9-1 mutant and analyzed the in vitro phenotypes of each revertant for coreversion to heat resistance. Extracts made from revertants prp $9 R 1$ and $p r p 9 R 2$ are resistant to heat inactivation as judged by both splicing and spliceosome assembly assays (for prp $9 R 1$ see Figs. 3 and 4; for $\operatorname{prp} 9 R 2$, data not shown).

\section{Spliceosome assembly}

Previously, it had been shown that the prp5-1 and prp11-1 mutations inhibit spliceosome assembly, but the specific assembly steps affected were not known (Lin et al. 1987). We determined the earliest assembly steps at which the PRP5, PRP9, and PRP11 proteins act. Active or heat-inactivated mutant extracts were assayed for their abilities to form pre-spliceosome and spliceosome complexes as detected by a native gel electrophoretic assay that we developed (S.W. Ruby and J. Abelson, in prep.). The names, snRNP compositions, and order of formation of the pre-spliceosome complexes that we can detect in this assay are the following: $\delta$ (Ul snRNP), $\beta_{1}$ (U1/U2 snRNPs), $\alpha_{1}$ (U2/U4/U5/U6 snRNPs), $\alpha_{2}$ (U2/ U5/U6 snRNPs), and $\beta_{2}$, the spliceosome (U2/U5/U6 snRNPs). Heat inactivation of the prp5-1 or prp9-1 extract has no detectable effect on $\delta$ complex formation but inhibits U2 snRNP binding and $\beta_{1}$ formation (Fig. 4, lanes $3,4,9,10,13,14)$ as does inactivation of prp11 extract (data not shown).

In an alternative approach, we analyzed the functions of the PRP5 and PRP11 proteins by an antibody inhibition assay. Pretreatment of active wild-type splicing extracts with either anti-PRP11 antibodies (Fig. 5) or antiPRP5 antibodies (data not shown) prevents U2 snRNP binding, whereas pretreatment with preimmune sera has no effect. Pretreatment with anti-PRP4 antibody, which we used as another control because it blocks binding of the U4/U5/U6 tri-snRNP (Banroques and Abelson 1989), results in accumulation of the $\beta_{1}$ complex (Fig. 5). We conclude that the PRP5, PRP9, and PRP11 proteins are required for U2 snRNP to bind to the pre-mRNA to form the $\beta_{1}$ complex.

\section{Immunoprecipitation of snRNPs and pre-mRNA with anti-PRP11 antibody}

To further elucidate the role of PRP11 protein in spliceosome formation, we assayed whether PRP11 protein associates with any snRNP or only with the spliceosome. The PRP11 protein was immunoprecipitated with anti-PRP11 antibody from an active, wild-type, wholecell splicing extract without pre-mRNA. Coprecipitating RNAs were extracted and detected in two ways: They were radiolabeled at their $3^{\prime}$ ends (Fig. 6A), or hybridized with snRNA-specific probes (Fig. 6B). The U2, U4, U5, 


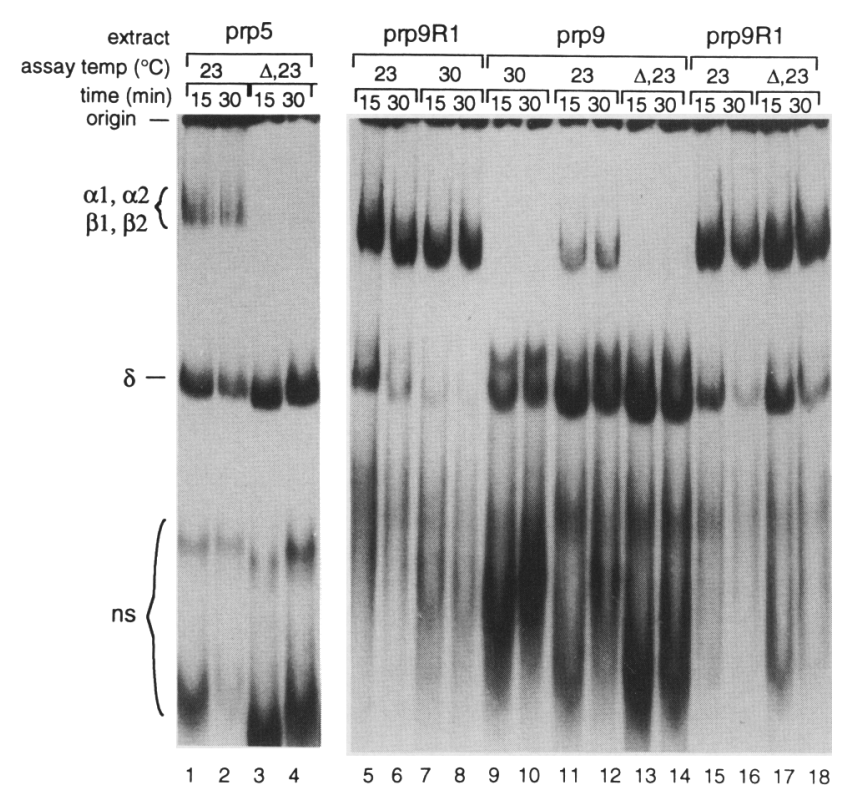

Figure 4. Pre-spliceosome complexes formed in heat-inactivated prp mutant and control extracts. Active and heat-inactivated splicing extracts from mutants prp5-1 (lanes 1-4), and prp9-1 (lanes 9-14) and the reverant prp9R1 (lanes 5-8 and lanes 15-18) were assayed for their snRNP-binding activities. In one set of inactivation conditions (indicated by $\Delta, 23$ ), the extracts were first inactivated by incubation at $38^{\circ} \mathrm{C}$ for $10 \mathrm{~min}$ and then assayed for spliceosome formation by the addition of splicing buffer components, ATP, and radiolabeled pre-mRNA. The reactions were incubated at $23^{\circ} \mathrm{C}$ for 15 and $30 \mathrm{~min}$ : prp5 (lanes 3,4); prp9 (lanes 13,14); and prp9R1 (lanes 17,18). In the other set of inactivation conditions (assay temperature at $30^{\circ} \mathrm{C}$ ), the splicing assays were initiated by mixing the components and radiolabeled pre-mRNA pre-equilibrated at $30^{\circ} \mathrm{C}$ for $2 \mathrm{~min}$, and then incubated at $30^{\circ} \mathrm{C}$ for the times indicated. All reactions were quenched at $0^{\circ} \mathrm{C}$. The snRNP/pre-mRNA complexes formed in the assays were resolved by native gel electrophoresis and visualized by autoradiography as shown here. The positions of the snRNP/pre-mRNA complexes are indicated: [U1/pre-mRNA $(\delta), \mathrm{U} 1 / \mathrm{U} 2 /$ pre-mRNA $\left(\beta_{1}\right), \mathrm{U} 2 / \mathrm{U} 4 / \mathrm{U} 5 / \mathrm{U} 6 /$ pre-mRNA $\left(\alpha_{1}\right)$, U2/U5/U6/pre-mRNA $\left(\alpha_{2}\right) \mid$, the spliceosome $\left(\beta_{2}\right)$, and the nonspecific (ns) complexes are indicated. The order of formation of the pre-spliceosome complexes is $\delta, \beta_{1}, \alpha_{1}, \alpha_{2}$, and $\beta_{2}$ (S.W. Ruby and J. Abelson, in prep.). The latter four complexes are not resolved in this assay.

and U6 snRNPs specifically coprecipitate with the PRP11 protein when the immunoprecipitations are performed with low to mildly stringent conditions $150-150$ $\mathrm{mM}$ salt washes with or without heparin). The Ul snRNP coprecipitates poorly or not at all, heparin, which reduces nonspecific associations of snRNPs in the immunoprecipitates, abolishes U1 snRNP coprecipitation (Fig. 6B). The levels of coprecipitating U2, U4, U5, and U6 snRNPs decrease with increasing salt concentrations in the immunoprecipitation assay (Fig. 6). These coprecipitation patterns differ markedly from those in which proteins are integral components of snRNPs. For example, anti-PRP4 antibody precipitates the U4, U5, and U6 snRNAs under the same assay conditions (Fig. 6A). Fur- thermore, the PRP4 protein has been shown previously to remain snRNP-associated even in $500 \mathrm{mM} \mathrm{NaCl}$ with heparin (Banroques and Abelson 1989). We conclude that PRP11 does associate with one or more snRNPs but that this association is salt sensitive and may be readily reversed.

Previously, we had shown that PRP11 protein associates with the spliceosome (Chang et al. 1988). We asked here when it enters the complex as determined by immunoprecipitation assays. One consideration was that endogenous levels of ATP in the extract could be high enough to promote PRP11 binding to the pre-spliceosome if PRP11 binding was ATP dependent. We therefore used conditions to deplete the extracts of ATP (see Materials and methods). Radiolabeled premRNA was added to an active wild-type splicing extract with or without ATP. At various times thereafter, we assayed the reactions for coprecipitation of the pre-mRNA with anti-PRP11 antibody. We find that the pre-mRNA associates with the PRP1l protein in both the absence and

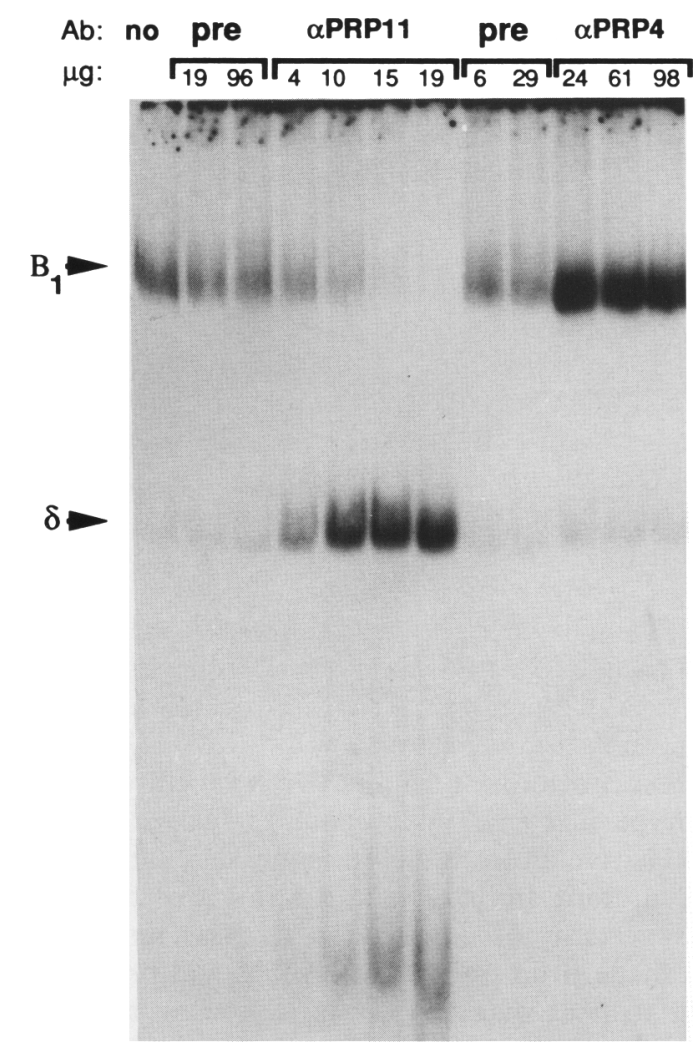

Figure 5. Antibody inhibition of pre-spliceosome complex formation. A wild-type splicing extract was treated with various amounts of anti-PRP11 ( $\alpha$ PRP11) or antiPRP4 ( $\alpha$ PRP4) antibodies, or the respective preimmune (pre) antibodies. Spliceosome formation assays were then initiated by the addition of splicing buffer components, ATP, and radiolabeled pre-mRNA. After 20 min at $23^{\circ} \mathrm{C}$, the reactions were quenched at $0^{\circ} \mathrm{C}$ and analyzed by native gel electrophoresis. The pre-spliceosome and spliceosome complexes were visualized by autoradiography as shown here. The positions of the $\delta$ and $\beta_{1}$ complexes are indicated. 


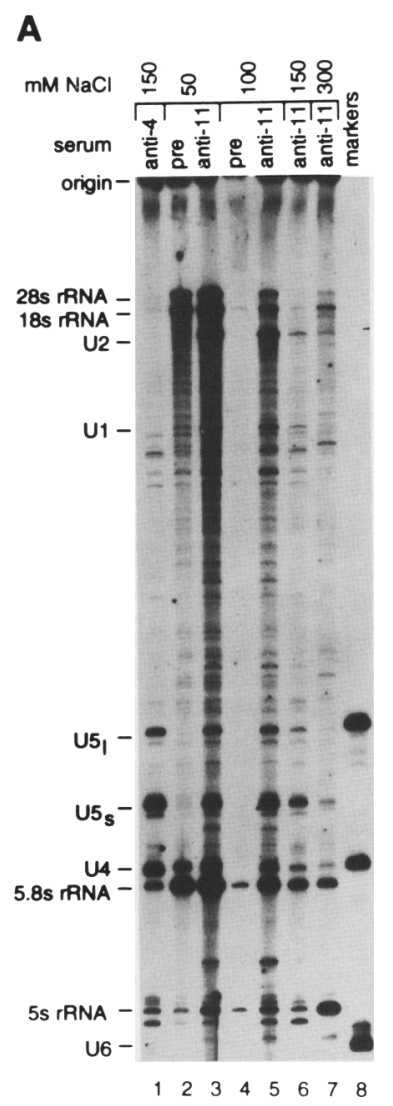

B

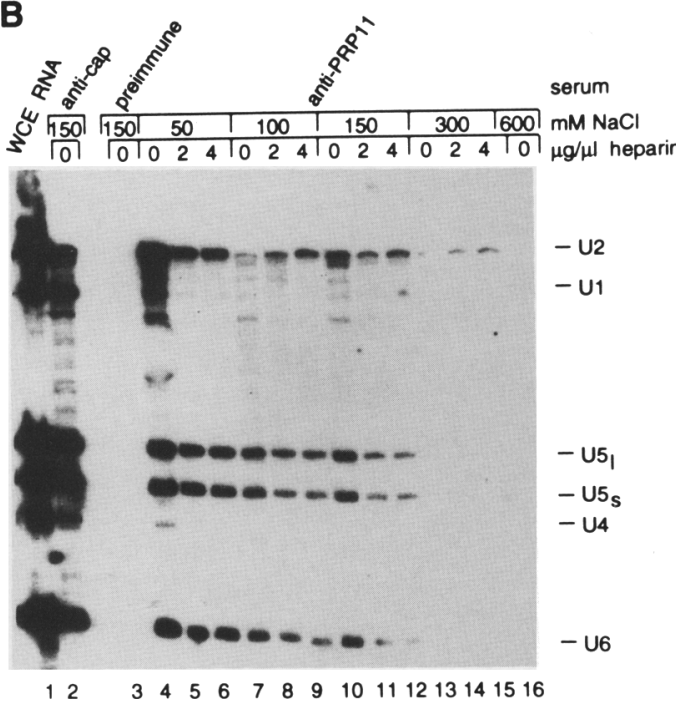

Figure 6. Immunoprecipitation of snRNPs with anti-PRPll antibody. (A) RNAs coprecipitating with the PRP4 or PRP11 proteins from whole-cell splicing extract treated with antibodies were radiolabeled at their $3^{\prime}$ ends with $\left[{ }^{32} \mathrm{P}\right] \mathrm{pCp}$ and T4 RNA ligase and analyzed by denaturing polyacrylamide gel electrophoresis and autoradiography as shown here. Either anti-PRP4 (lane 1), preimmune (lanes 2,4), or anti-PRP11 (lanes 3,5-8) serum was used for the immunoprecipitations. The immunoprecipitates were washed with various salt concentrations as indicated before the RNAs were extracted. In vitro-synthesized, radiolabeled $\mathrm{U} 4, \mathrm{U} 5_{\text {long, }}$ and $\mathrm{U} 6$ RNAs serve as markers. The bands corresponding to ribosomal RNAs, U2, U1, U4, U6, and the two forms of U5 (long and short) RNAs are indicated. The U6 snRNA cannot be seen in immunoprecipitates because it cannot be radiolabeled at its $3^{\prime}$ end. (B) RNAs that coprecipitate with the PRP11 protein from whole-cell splicing extract were analyzed by denaturing gel electrophoresis, Northern blot hybridization, and autoradiography as shown here. Either anti-trimethylcap (lane 2), preimmune (lane 3) or anti-PRP11 (lanes 4-16) serum was used for the immunoprecipitations. The immunoprecipitates were washed with various concentrations of salt and heparin as indicated before the RNAs were extracted. The U1, U2, U4, U5 long, $_{\text {U }}$ short $_{\text {, }}$ and U6 snRNAs were detected by simultaneous hybridization with the snRNA-specific probes. (There was less U4 snRNA probe used relative to the other probes in this particular assay; therefore, less U4 snRNA than normal was detected. Usually we detect U4 snRNA when we detect the other snRNAs in this assay.) Total RNA extracted from whole-cell splicing extract was used for markers (lane 1).

presence of ATP (Fig. 7A). This suggests that PRP11 protein is in the earliest detectable pre-spliceosome complex, the $\delta$ complex, as the Ul snRNP is the only snRNP that binds to the pre-mRNA in the absence of ATP (Bindereiff and Green 1987; Ruby and Abelson 1988; Rosbash and Seraphin 1991). Pre-mRNAs that are not active splicing substrates and bind reduced amounts of U1 snRNP (Ruby and Abelson 1988) coprecipitate poorly with the PRP11 protein (Fig. 7B): The mean level of coprecipitating pre-mRNA with the branch point region mutation (UACaAAC) was only $25 \%(n=3$, s.D. $=6.3)$ that of wild-type pre-mRNA. The mean level of copre-
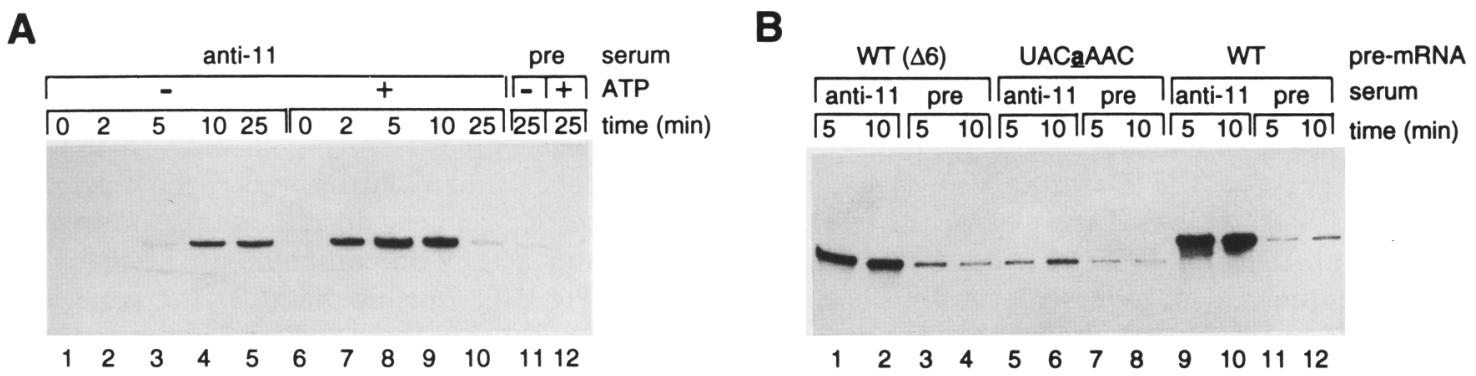

Figure 7. Immunoprecipitation of pre-mRNAs with anti-PRPIl antibody. (A) Radiolabeled wild-type pre-mRNA was added to splicing assays without (lanes 1-5,11) or with (lanes 6-10,12) ATP. At various times thereafter, the assays were immunoprecipitated with either anti-PRP11 (anti-11; lanes 1-10) or preimmune (pre; lanes 11,12) sera. Coprecipitating RNAs were extracted and analyzed by denaturing gel electrophoresis and autoradiography as shown here. Only significant levels of pre-mRNA were immunoprecipitated; splicing intermediates and products were not detectable above background (preimmune) levels. Analysis of the RNAs in parallel splicing reactions with ATP showed that the pre-mRNA was spliced (data not shown). $(B)$ Radiolabeled wild-type [WT or WT( $\Delta 6$ )] or mutant (UACaAAC) pre-mRNA was added to splicing assays with ATP. After 5 or 10 min of incubation, the RNAs were analyzed as in $A$. The WT $(\Delta 6)$ pre-mRNA has the 6-nucleotide cryptic branchpoint sequence deleted but splices as efficiently as wild-type pre-mRNA (Vijayraghavan et al. 1986). The mutant (UACaAAC) pre-mRNA is not an active splicing substrate: It binds reduced amounts of U1 snRNP (Ruby and Abelson 1988) and forms reduced amounts of the $\delta$ complex (S.W. Ruby and J. Abelson, in prep.). The $W T(\Delta 6)$ and mutant pre-mRNA have an exon 2 that is 100 nucleotides shorter than that of wild-type pre-mRNA (WT). 
cipitating $5^{\prime}$ splice site mutant pre-mRNA (cUAUGU) was also only $25 \%$ that of wild-type (data not shown). These levels are reduced but are still above the background levels $17 \%$ of the wild-type pre-mRNA; $n=5$, S.D. $=5$ ) that we obtained with a control RNA lacking an intron. We do not precipitate significant levels of splicing intermediates or products (Fig. 7A; lanes 8,9). Therefore, PRP11 may leave the spliceosome preceding the first splicing reaction, or the epitope may become inaccessible to the antibody at that time.

\section{Discussion}

Genetic evidence that PRP5, PRP9, PRP11, and PRP21 proteins interact functionally or physically

Potentially interacting proteins in several other cellular processes such as secretion (Salminen and Novick 1987; Rothblatt et al. 1989), translation (Haffter et al. 1991), cytoskeletal assembly (Novick et al. 1989; Stearns et al 1990), transcription (Arndt et al. 1989), DNA replication (Hennessy et al. 1991), and morphogenesis (Bender and Pringle 1991) have been initially identified genetically. In four of these cases, it has now been shown by biochemical assays that the genetic interactions predicted actual physical or functional interactions (Adams et al. 1989; Arndt et al. 1989; Deshaies et al. 1991; Rossi et al. 1991). For example, mutations in the SAC6 and ACT1 genes can suppress each other's defects (Adams and Botstein 1989), and the SAC6 protein binds to polymerized actin (Adams et al. 1989).

We found that the prp5, prp9, prp11, and prp21 mutations act synergistically with each other but not with other prp mutations such as prp16-2, prp17-1, and prp181 . These latter three mutations have been shown previously to result in defects in the second reaction step of splicing (for review, see Guthrie 1991; Ruby and Abelson 1991; Brown et al. 1992). Similarly, the mutations prp162, prp17-1, and prp18-1 have synergistic effects among each other but not with prp mutations that act at earlier or later steps (Frank et al. 1992). This specificity argues that the synergisms we observe in the haploid double mutants are attributable to specific functional or physical interactions among the encoded gene products. The fact that the four genes, PRP5 (Dalbadie-McFarland and Abelson 1990), PRP9 (Legrain and Choulika 1990), PRP11 (Chang et al. 1988), and PRP21 (Arenas and Abelson 1993/ are unique and encode structurally distinct proteins, makes it unlikely that their functions are redundant.

The specificity of the interactions among the PRP5, $P R P 9, P R P 11$, and $P R P 21$ genes is supported further by our finding that high copies of the PRP9 or PRP11 wildtype gene can partially suppress mutations in some of the other genes of this set. The suppression of the prp5-1 and prp21-1 mutations by the wild-type $P R P 9$ gene is particularly noteworthy. $P R P 9$ partially suppresses the prp5-1 but not the prp5-3 mutation, an allele-specific effect, suggesting that elevated $P R P 9$ levels neither bypass PRP5 function nor generally stabilize mutant pro- teins. While our work was in progress, the SPP91 gene was isolated as a second site suppressor of prp9 mutations (Chapon and Legrain 1992) and subsequently identified as PRP21 (Arenas and Abelson 1993). SPP91 cannot functionally replace $P R P 9$ (Chapon and Legrain 1992), therefore, the suppressor activities of SPP91 (Chapon and Legrain 1992) and $P R P 9$ (this paper) are not attributable to functional replacement. We also find that the suppressor activity of PRP11 is weaker than that of PRP9 but, nonetheless, significant. A previous study has reported that PRP11 was unable to suppress the prp9-1 mutation (Last et al. 1987); however, this study did not assay temperature sensitivities at the intermediate temperatures as we have done here. The suppressor activities of $P R P 9$ and PRP11 that we see are consistent with our results that the prp5, prp9, prp11, and prp21 mutations act synergistically with each other and further support our hypothesis that the four proteins are interacting functionally or physically. Recently, possible physical interactions between the PRP9, PRP11, and PRP21 proteins have also been detected in vivo by the two-hybrid transcription activation assay (Legrain et al. 1993; Legrain and Chapon 1993).

We also genetically detected interactions between three proteins [PRP3 (Last and Woolford as cited in Ruby and Abelson 1991), PRP4 (Banroques and Abelson 1989; Bjorn et al. 1989), and PRP24 (Shannon and Guthrie 1991/| known to be in the U4/U6 snRNP; either combination of mutations prp3 and prp 4 or prp 4 and prp24 is lethal in a haploid. We do not detect any interactions between PRP6, another U4/U6 snRNP protein (Abovich et al. 1990), and these three proteins; however, we cannot conclude that PRP6 protein does not interact with these proteins. In some instances, two proteins have been biochemically shown to interact, but these interactions cannot be detected genetically (see, e.g., Bacon et al. 1989 and Salminen and Novick 1989|.

\section{Biochemical evidence that the PRP9 and PRP11 proteins interact with each other and with the U2 snRNP}

Both the PRP9 (Abovich et al. 1990) and PRP11 proteins are required for $U 2$ snRNP to bind to the pre-spliceosome (Figs. 4 and 5). Furthermore, the inactivated prp9-1 and prp11-1 extracts do not complement one another even though they do complement other inactivated extracts (Fig. 1B). Our biochemical and genetic data combined suggest that these two proteins may interact physically in a complex or as parts of two complexes composed of subunits that do not exchange in the inactivated extracts. Our previous biochemical data also suggest that the PRP11 protein is in a complex. The wild-type PRP11 protein complements inactivated prp11-1 extracts only when present during heat inactivation of the mutant extract (Chang et al. 1988). Also, the wild-type protein associates with a $30 \mathrm{~S}$ particle in the absence of exogenous pre-mRNA. The size of this particle suggests that it could contain one or more snRNPs. Perhaps one of these is the U2 snRNP (see below). 
Additional support for the idea that the PRP9 and PRP11 proteins are in a complex comes from studies of mammalian splicing factors. We were excited to hear that the mammalian homologs of PRP9/A. Kramer, pers. comm.) and PRP11 (Bennett and Reed 1993) may have been identified. The two mammalian proteins are present in the mammalian pre-spliceosome complex A containing the $\mathrm{U} 1$ and $\mathrm{U} 2$ snRNPs and in the spliceosome (Bennett and Reed 1993). They also comprise two of the three subunits of mammalian splicing factor SF3a (Brosi et al. 1993a). SF3a is required for the formation of pre-spliceosome complex A (Kramer and Utans 1991; Brosi et al. 1993b). The biochemical characterization of SF3a is particularly pertinent to our suggestion that PRP9 and PRP1l are in a complex together, where they may interact physically. The fact that the three SF3a subunits copurify through many purification steps (Brosi et al. 1993a) is a good indication that these three proteins interact physically. It seems likely that PRP9 and PRP1 1 are part of the yeast homolog of SF3a. Either PRP5, PRP21, or some as yet unidentified protein could be the third subunit of the yeast SF3a.

We have found that the same subset of mutations (prp5, prp9, prp11, and prp21) that interact with each other also act synergistically with mutations in the stem-loop IIa of the U2 snRNA. Furthermore, additional genetic studies have revealed that some, but not all, mutations in $\mathrm{U} 2$ also have synergistic effects with this subset of prp mutations (S. Fischer-Wells and M. Ares, pers. comm.). These genetic data are consistent with other recent biochemical studies indicating that PRP9 and PRP11 proteins associate with the U2 snRNP. The yeast U2 snRNA immunoprecipitates with the PRP9 protein (Abovich et al. 1990). Nine mammalian proteins associate with the $5^{\prime}$ end of the U2 snRNA in the $17 \mathrm{~S}$ form of the snRNP (Behrens et al. 1993a); two of these proteins are the putative mammalian homologs of PRP9 and PRP11 (Behrens et al. 1993b; Brosi et al. 1993b; A. Kramer pers. comm.). The $5^{\prime}$ region of the snRNA includes the sites of the mutations that we tested in yeast.

Here, we attempted to determine whether PRP11 protein associates with the U2 snRNP by immunoprecipitation assays. We found, however, that anti-PRP11 antibody precipitates the U2, U4, U5, and U6 snRNPs from splicing extracts in the absence of pre-mRNA. Previously, it had been found that the U2, U4, U5, and U6 snRNAs also coprecipitated with an epitope-tagged PRP9 protein, although U2 was the predominant precipitating species (Abovich et al. 1990). The simplest explanation for our result is that the other snRNPs coprecipitate with anti-PRP11 antibody because they are associating with the U2 snRNP. Complexes composed of several snRNPs in the absence of a pre-mRNA have been observed (Cheng and Abelson 1987; Konarska 1988; Hall and Konarska 1992). We cannot, however, exclude the possibilities that PRP11 associates with more than one snRNP and that PRP11 has functions in addition to promoting U2 snRNP binding to the pre-mRNA. The 5' region of the U2 snRNA is involved in base-pairing interactions in the spliceosome with the pre-mRNA branchpoint region (Parker et al. 1987; Zhuang and Weiner 1989) and the U6 snRNA (Hausner et al. 1990; Datta and Weiner 1991; Wu and Manley 1991; Madhani and Guthrie 1992; McPheeters and Abelson 1992). Perhaps PRP11 is also involved in U2/U6 snRNP interactions.

Our other immunoprecipitation assays also indicate that PRP11 associates with the pre-mRNA in the absence of ATP before U2 snRNP binds to the pre-mRNA. The simplest interpretation of our results is that the step at which PRP11 binds to the $\delta$ complex is distinct from the step of U2 snRNP binding when it is required. In this way, PRP11 resembles the mammalian splicing factor U2AF (Zamore and Green 1989). This factor binds to the pre-mRNA in the absence of ATP and is required for the U2 snRNP to bind to the pre-spliceosome complex. We therefore suggest that the PRP9 protein and the U2 snRNP interact physically, and that they interact physically with PRP11 in the pre-spliceosome $\beta_{1}$ complex. These physical interactions, as well as the stoichiometries of the PRP9 and PRP11 proteins in the pre-spliceosome complexes, remain to be established.

We have found that PRP11 associates with pre-mRNAs that are active substrates for splicing but associates poorly with mutant pre-mRNAs that do not splice and bind reduced amounts of U1 snRNP. Perhaps PRP11 binding depends on the U1 snRNP; however, we could not detect here any direct association of PRP11 with the U1 snRNP. The U1 snRNP did not precipitate with antiPRP11 antibody in the absence of pre-mRNA (Fig. 6). Other experiments are needed to establish whether PRPII is binding to the pre-mRNA and/or if its binding is dependent on other factors.

\section{Roles of PRP5 and ATP in spliceosome assembly}

Here, we have shown that PRP5 protein is required for U2 snRNP to bind to the pre-mRNA to form the prespliceosome $\beta_{1}$ complex containing the $U 1$ and $U_{2}$ snRNPs. U2 snRNP binding is the first step in the spliceosome assembly pathway that requires ATP hydrolysis (Liao et al. 1992). The function of the PRP5 protein may explain the roles for ATP at this step. As a member of the DEAD-box protein family (Dalbadie-McFarland and Abelson 1990), PRP5 closely resembles the translation inititiation factor eIF4A that has been shown to have RNA-dependent ATPase and RNA helicase activities (for review, see Wassarman and Steitz 1991; Schmid and Linder 1992). eIF4A binds to the mRNA during translation initiation, unwinds helices upstream of the AUG codon, and thereby allows the 40S ribosomal subunit to bind to the mRNA (for review, see Linder and Prat 1990). PRP5 may have an analogous role in spliceosome assembly. PRP5 does have an RNA-dependent ATPase activity, but it is not yet known whether it has RNA-unwinding activity (C. O'Day and J. Abelson, unpubl.). If PRP5 is an RNA helicase, it could alter either the U1 snRNP/pre-mRNA $\delta$ complex or the U2 snRNP.

Another similarity between PRP5 and eIF4A suggests that factors interacting with PRP5 could modulate PRP5 
activity. Our data suggest that PRP5 acts concertedly or interacts with three other proteins to promote U2 snRNP binding. eIF4A acts concertedly with eIF4B and eIF4F to bind the ribosome to mRNA (for review, see Sonenberg 1988; Linder and Prat 1990). eIF4A alone has some enzymatic activity; however, when it is in a multisubunit complex, its activity is enhanced (Ray et al. 1985; Rozen et al. 1990; Pause and Sonenberg 1992).

A second role for ATP and PRP5 could be in the recognition and selection of both the $5^{\prime}$ and $3^{\prime}$ pre-mRNA splice sites. The stability of the Ul snRNP bound to the pre-mRNA and the rate of ATP hydrolysis could determine which splice sites among alternative splice sites are utilized via a mechanism similar to one proposed for kinetic proofreading by the PRP16 protein in the second splicing reaction step (Burgess et al. 1990).

Previously, we (Ruby and Abelson 1988) and others (Seraphin and Rosbash 1989; Rosbash and Seraphin 1991) have suggested that some factor may mediate the interaction of the U1 snRNP with the branch point region in the $\delta$ complex and be required for forming that complex. Neither PRP5, PRP9, nor PRP11 appears to be this factor. We find that a $\delta$ complex still forms when any one of these proteins is inactivated.

\section{Model for U2 snRNP binding to the pre- spliceosome complex}

Our current working model for the functions of the PRP5, PRP9, PRP11, and PRP21 proteins is illustrated in Figure 8. We have depicted PRP5 and PRP11 as present in the $\delta$ complex because we have shown that the PRP11 (this paper) and PRP5 (C. O'Day and J. Abelson, unpubl.) proteins associate with the pre-mRNA in the absence of ATP. We do not know whether either PRP11 or PRP5 can associate with the pre-mRNA before Ul binds, but neither protein is required for U1 snRNP binding. PRP5 protein may associate only transiently with the $\delta$ complex if it functions like two other putative helicases, PRP16 (Schwer and Guthrie 1991) and PRP2 (King and Beggs 1990; Kim and Lin 1993), which interact transiently with the spliceosome at later steps. We have not included the PRP9 and PRP21 proteins in this complex on the basis of previous observations by others. PRP9 does not coprecipitate with the pre-mRNA unless the U2 snRNP is intact (Abovich et al. 1990), and an association of the U2 snRNP with the pre-mRNA in the absence of ATP in the yeast in vitro system has not been observed (Ruby and Abelson 1988; Liao et al. 1992). Anti-PRP21 antibody does not coprecipitate pre-mRNA in the absence of ATP (Arenas and Abelson 1993).

Several data suggest that PRP9, PRP11, and PRP21 proteins are present in the $\beta_{1}$ complex. We have shown here that PRP11 immunoprecipitates with the pre-mRNA in the presence of ATP. Previously, we have shown that it cosediments with a large, $40 \mathrm{~S}$ particle that is either the spliceosome or a complex immediately preceding the active spliceosome (Chang et al. 1988). Both PRP9 (Abovich et al. 1990) and PRP21 (Arenas and Abelson 1993) proteins coprecipitate with pre-mRNA in the presence of
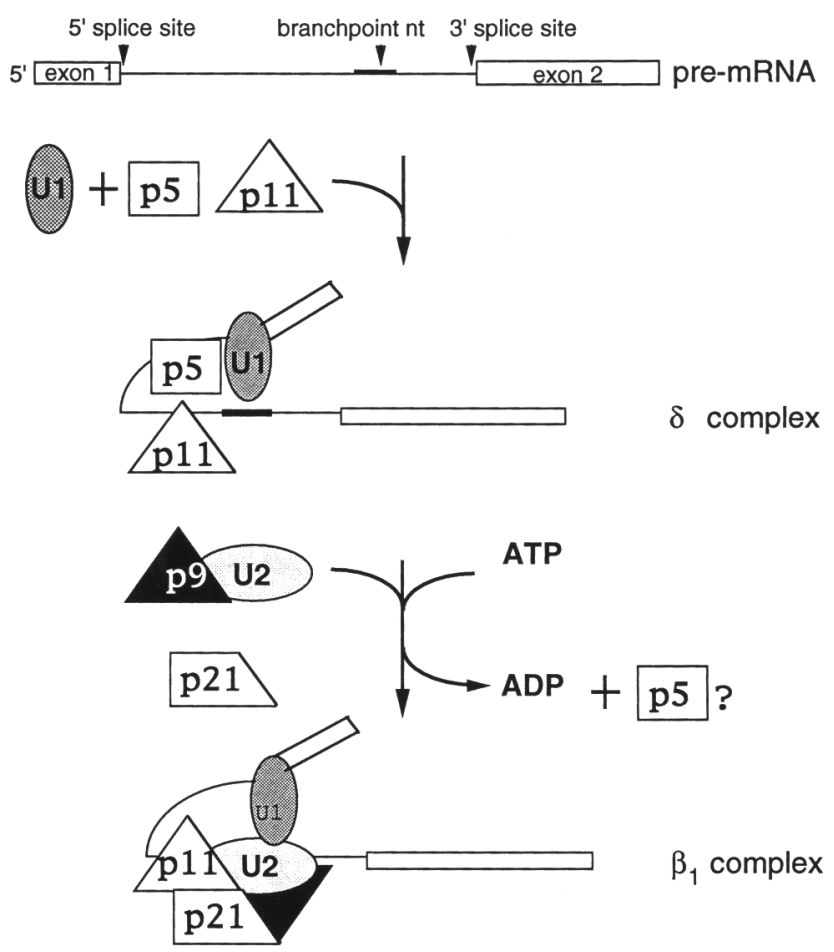

Figure 8. Model showing PRP5, PRP9, PRP11, and PRP21 proteins promoting $U 2$ binding to the pre-spliceosome complex. During formation of the $\delta$ complex, the Ul snRNP binds to the pre-mRNA. The PRP11 and PRP5 are present in the $\delta$ complex, but we do not know when they enter the complex. In the next step, U2 snRNP, perhaps with the PRP9 protein, binds to the complex. PRP21 protein also associates with the $\beta_{1}$ complex as well, but it may do so only as U2 snRNP binds to the complex. The three proteins, PRP9, PRP11, and PRP21, at this point become integral components of the $\beta_{1}$ complex. PRP5 protein may act concurrently with the binding of the U2 snRNP. Thereafter, PRP5 may leave the complex. The positions and stoichiometries of the PRP proteins relative to each other and to the snRNPs within the pre-spliceosome complexes as well as the association of the U1 snRNP with the intron branchpoint and the U2 snRNP are arbitrarily drawn.

ATP. PRP21 protein is required for formation of the $\beta_{1}$ complex (Arenas and Abelson 1993). Whether PRP21 is bound to the U2 snRNP before it enters the complex is not known, but it seems unlikely as PRP21 coprecipitates with the pre-spliceosome complex but not with free U2 snRNP (Arenas and Abelson 1993).

Several aspects regarding how these four proteins act to promote U2 snRNP binding need to be elucidated. In particular, the order of events regarding the actions of these proteins and the base pairing between the $\mathrm{U} 2$. snRNA and the pre-mRNA branchpoint region has to be determined. This order has important implications for understanding the recognition and selection of splice sites. For example, in one possible order of events, the initial contact between the U2 snRNP and the premRNA complex could occur by protein-protein and/or U1/U2 snRNP interactions. The U2 snRNA could 
then base-pair with the pre-mRNA via the branchpoint region. Previous observations in yeast on the dominant in vivo lethal effects of a mutant U2 snRNA with an altered branchpoint recognition sequence could be explained by this order (Miraglia et al. 1991). An interaction between PRP9 and PRP11 could be involved in this initial recognition event.

\section{Materials and methods}

Plasmids

Five plasmids were constructed. Plasmid pCEN-prp11.1 was constructed by subcloning a HindIII-EcoRI fragment containing the prp11-1 allele from PFL39-prp11.1 (Schappert and Friesen 1991) into a yeast shuttle vector, pRS416 (CEN-ARS-URA3) (Christianson et al. 1992). Plasmids pCEN-PRP11 and p2 $\mu-$ $P R P 11$ were generated by subcloning the $2.7-\mathrm{kb} B a m H I-H i n d I I I$ fragment covering the entire coding region of $P R P 11$ (Chang et al. 1988) into two yeast shuttle vectors, pSEY18 $(2 \mu-U R A 3)$ and pSEYC68 (CEN-URA3). Plasmid pprp9::HIS3 was constructed by ligating a gel-purified $1.7-\mathrm{kb}$ SmaI-HincII HIS3 gene fragment from plasmid pJ/215 (Jones and Prakash 1990) to EcoRVcut plasmid pPL5: Digestion of pPL5 with EcoRV removed a 700-bp fragment from the $P R P 9$ protein-coding sequence, and the ligation was done in the presence of EcoRV enzyme to enrich for the correct construct. Plasmid pPS6 $(2 \mu-U R A 3)$ was constructed by subcloning a $2.3-\mathrm{kb}$ BamHI-HindIII containing the entire coding region of $P R P 9$ onto the yeast shuttle vector pRS426 (2 $\mu-U R A 3)$.

The following plasmids were obtained: pGD231 (CEN-ARSURA3-PRP5) (Dalbadie-McFarland and Abelson 1989) and pGD532 (2 $\mu-H I S-P R P 5)$ from G. Dalbadie-McFarland; pPL4 (CEN-ARS-URA3-PRP9) (Legrain and Choulika 1990) and pPL5 (Legrain et al. 1991) from P. Legrain; pPL39-prp11.1 and pprp11::HIS3 from K. Schappert (University of California, San Diego); pRS416 and 426 (Christianson et al. 1992) from B. Sikorski; pSEY 18 and pSEY68 from S. Emr (University of California, San Diego); pJJ215 from M. Werner-Washburn (University of New Mexico, Albuquerque); YCp-LEU2-U2, YCp-LEU2$\mathrm{U} 2(\mathrm{G} 53 \mathrm{~A}$ ), YCp-LEU2-U2(C62U), and $\mathrm{pU} 2:: U R A 3$ (Ares and Igel 1990) from $M$. Ares.

\section{Strains}

The relevant genotypes of strains acquired for use in this study were the following: SS328 (Mat $\alpha$ ade2-101 his3-d200 lys2-801 ura3-52), SS330 (Mata ade2-101 his3-d200 tyr1 ura3-52), SS304

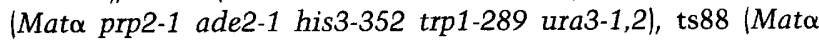

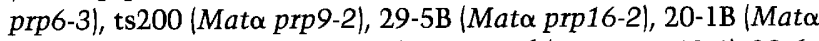
prp17-1), 27-6C (Mato prp18-1), H-10a-3d (Mato prp19-1), 20-6a

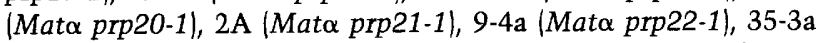

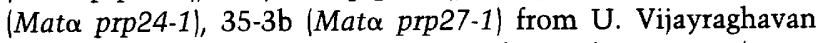
and M. Company (Vijayraghavan et al. 1989); SPJ 4.43 (Mata prp4-1), ts257\#12 (Mata prp9-1 ade- his4 leu2 trp1 ura1),

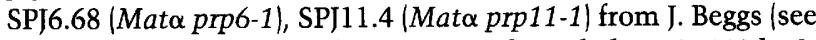
Lustig et al. 1986); JM275 (Mata prp5-3 his3-d1 leu2-3,-112 lys2801 ura3-52) from J. Beggs; ma3-1 (Mata prp3-1) from the Yeast Genetic Stock Center; RL172 (Mat $\alpha$ prp5-1) from R. Last and J. Woolford (see Lustig et al. 1986); HI70-wt [Mata leu2-3,112 his4-619 lys2 U2::Ura3 (YCp-LEU2-U2wt)], HI70-G53A [Mata leu2-3,112 his4-619 lys2 U2::Ura3 (YCp-LEU2U2G53A)], and HI70-C62U [Mata leu23,112 his4-619 lys2 $U 2:: U r a 3$ (YCp-LEU2-U2C62U)] from M. Ares (Ares and Igel 1990); and EJ101 (Mata pep4-3) from E. Jones (see Lin et al. 1985). We used standard genetic techniques (Guthrie and Fink
1990 ) except that all matings, sponulations, and tetrad analyses were done at $23^{\circ} \mathrm{C}$.

We created a set of strains with the various prp mutations in the SS330 strain background. The strains carrying the prp2-1, prp3-1, prp4-1, prp5-1, prp5-3, prp6-1, prp8-1, prp9-1, and prp11-1 mutations were crossed into SS330 or the congenic strain, SS328 and then crossed at least twice again into SS330. The original isolates with the prp6-3, prp9-2, and prp16-2 through 27-1, mutations had been generated previously in SS330 or SS328 and crossed out at least once into the parent strain (Vijayraghavan et al. 1989). The strains carrying these mutations were crossed at least once again into SS330 or two other wild-type congenic strains, SRYWTa (Mata his3-d200 his4 leu2 trp ${ }^{-}$try1 ura1 ura3-52) or SRYWTb (Mata his3-d200 leu2 tyr1 ura3-52). These latter two wild-type strains were generated after three backcrosses of strain TS257\#12 into SS330. SRYWTa and SRYWTb were used to increase spore viability and sporulation frequency or to introduce the leu2 mutation. In the tetrad analyses where we observed reduced spore viability or sporulation frequency because of nonspecific reasons, a strain was crossed again into strain SRYWTa or SRYWTb and then used in the analyses. A third wild-type strain, SRYWTd (Mata ade $e^{-}$his3-d200 leu2 tyr1 ura3-52), was created by backcrossing SRYWTa again into SS330 and used in some crosses. Strains in the set used for all of the genetic analyses are designated SRY21a (Mata prp2-1 ade2 his3 try1 trp1-289 ura-), SRY2-1b (Mat $\alpha$ prp2-1 ade2 his3 tyr1 ura-), SRY3-1a (Mata prp3-1 ade his3 try1 ura ${ }^{-}$), SRY3-1b (Mata prp3-1 ade- his3 leu2 ura- ), etc. A complete list of these strains and their genotypes is available on request.

Revertants prp9-1R1 and prp9-1R2 were obtained by irradiating strain Ts $257 \# 12$, respectively with $30 \mathrm{~J} / \mathrm{m}^{2}$ ultraviolet light and selecting for growth at $37^{\circ} \mathrm{C}$. Genetic analyses showed that the prp $9 R 1$ and prp $9 R 2$ mutations are tightly linked to the $P R P 9$ gene and, thus, probably intragenic.

We constructed several strains by transformation with the method of Ito et al. (1983). Strains SRY9-1c (Mata prp9-1 his3-

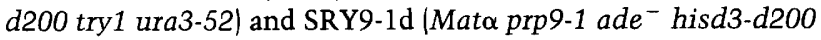
leu2 tyr1 ura3-52), or SRY9-2e (Mata prp9-2 ade his3-d200 $^{-}$ tyr1 ura3-52) and SRY9-2f (Mata prp9-2 ade- hisd3-d200 leu2 trp ${ }^{-}$tyr1 ura3-52) were mated to create diploid DSR1314 or DSR1373, respectively. These diploid strains were transformed with the $3.1-\mathrm{kb}$ PstI-EcoRI fragment from plasmid pprp11::HIS3 to create the heterozygote TSR1127 (PRP11) prp11::HIS3, prp9-1/prp9-1) or TSR1129 (PRP11/prp11::HIS3, prp9-2/prp9-2). The pprp11::HIS3 plasmid has $\sim 700$ bp of the PRP11 protein-coding sequence beginning with codon 92 , substituted with the $1.8-\mathrm{kb}$ BamHI-HIS3 fragment. The positions of the prp11 null mutations were confirmed by Southern blot hybridization and tetrad analyses (data not shown). Plasmid pCEN-prp11-1 or pCEN-PRP11 was then introduced into each heterozygote by transformation to give the following strains: TSR244 (prp9-1/prp9-1, PRP11/prp11::HIS3, pCEN-PRP11); TSR243 (prp9-1/prp9-1, PRP11/prp11::HIS3, pCEN-prp11-1); TSR249 (prp9-2/prp9-2, PRP11/prp11::HIS3, pCEN-PRP11); and TSR250 (prp9-2/prp9-2, PRP11/prp11::HIS3, pCENprp11.1). Diploid DSR1401 was created by mating SRYWTd with SS330. This diploid was transformed with the $3.5-\mathrm{kb}$ SmaI-SalI fragment from plasmid pprp $9::$ HIS3 to create the heterozygote TSR 1252 (PRP9/prp9::HIS3). The position of the null mutation was confirmed as described above (data not shown). Plasmid pPL4 or pCEN-PRP11 was then introduced into this strain to create strain TSR 1262 (PRP9/prp9::HIS3, pPL4) or TSR1254 (PRP9/prp9::HIS3, pCEN-PRP11).

To study the interaction between the PRP5 and SNR20 genes in vivo, we designed a diploid strain that is homozygous for 
prp5-1 and heterozygous for a null, URA3-disrupted chromosomal copy of the SNR20 gene. Strains SRY5-1b (Mat $\alpha$ prp5-1 ade ${ }^{-}$his3-d200 leu2 tyr ${ }^{-}$ura3-52) and SRY5-1c (Mata prp5-1 ade- his3-d200 leu2 tyr ${ }^{-}$ura3-52) were mated to create diploid DSR1366. This diploid was transformed with a $4.5-\mathrm{kb}$ PstIEcoRI fragment from plasmid, psnr20::URA3 to create the SNR20/snr20::URA3 heterozygote TSR1111. The position of the null mutation was confirmed as described above (data not shown). TSR1111 was then transformed with plasmid YCpLEU2-U2, YCp-LEU2-U2 (G53A), or YCp-LEU2-U2 (C62U). The phenotypes of the meiotic progeny were determined by replica-plating tests. The presence of the URA3 marker in the meiotic progeny was determined by complementation analyses.

Each strain, SRY5-1b, SRY5-3a (Mata prp5-3 ade- his3-d leu2-3,-112 tyr1- ura3-52), SRY6-1 a (Mata prp6-1 ade2-101 his3 lys2 ura3-52), SRY9-1a (Mata prp9-1 ade2 his3-d200 tyr1 ura352), SRY9-2a (Mata prp9-2 ade2-101 his3-d200 ura3-52), SRY111a (Mata prp11-1 ade2-101 his3-d200 tyr1 ura3-52) or SRY21-1a (Mata prp21-1 ade his $^{-}$tyr1 ura3-52) was transformed with plasmid pGD231, pGD531, pPL4, pPS6, pCEN-PRP11, p2 $\mu$ PRP11, pRS423 (2 $\mu-H I S 3)$, or pRS426 $(2 \mu-U R A 3)$, respectively, for the multicopy suppression assay.

\section{In vitro splicing assays}

Whole-cell splicing extracts (WCEs) were prepared from strains ts257\#12, SPJ6.68, SPJ11.4, prp9-1R1, and prp9-1R2 according to Lin et al. (1985) except that we used $300 \mu \mathrm{g} / \mathrm{ml}$ of Zymolyase100T (Seikagaku Kogyo). Wild-type WCE was made from strain EJ101 as described previously (Lin et al. 1985). Extracts from strain RL172 were gifts from P. Fabrizio and G. McFarland (California Institute of Technology, Pasadena).

The yeast actin precursor RNA for splicing assays was synthesized in vitro by runoff transcription of a cloned template with SP6 polymerase and $\left[{ }^{32}\right.$ P]UTP (Amersham, Inc.) as described previously (Lin et al. 1985). The template was cut with HpaII restriction endonuclease for synthesizing the transcripts used in the native gel electrophoretic assays. The wild-type (actin $\Delta 6$ l, and mutant templates were cut with HpaII restriction endonuclease for synthesizing the transcripts used in the immunoprecipitation assays.

To heat-inactivate an extract by short heat treatments, $\mathrm{MgCl}_{2}$ was added to $1.5 \mathrm{mM}$, and the extract was incubated at $38^{\circ} \mathrm{C}$ for the times indicated. The extract was then kept on ice or frozen in liquid $\mathrm{N}_{2}$ until it was used. The splicing assays were incubated at $23^{\circ} \mathrm{C}$ for $30 \mathrm{~min}$ and processed as described (Lustig et al. $1986)$. For splicing assays at $30^{\circ} \mathrm{C}$, the extract $(40 \%$ of the reaction volume) was mixed with splicing buffer components and incubated for $2 \mathrm{~min}$ at $30^{\circ} \mathrm{C}$, after which the reaction was initiated by the addition of 4 fmoles of ${ }^{32} \mathrm{P}$-labeled pre-RNA and 15 nmoles of ATP. For complementation assays, the mutant extracts were inactivated by short heat treatments at $38^{\circ} \mathrm{C}$ for 8 min (for prp 9 and prp11 extracts) or $10 \mathrm{~min}$ (for prp5 and prp6 extracts). The complementation assays were as described by Lustig et al. (1986).

\section{Immunoprecipitations}

Immunoprecipitations of the snRNPs from WCEs with antiPRP11 or preimmune sera were done essentially as described (Banroques and Abelson 1987), except that $8 \mu 1$ of serum was used in the experiments. Five microliters of wild-type WCE was incubated in splicing buffer without ATP or pre-mRNA at $23^{\circ} \mathrm{C}$ for $25 \mathrm{~min}$. Sodium heparin (Sigma) was then added as indicated, and the mixture was next added to the antibody immobilized on protein A-Sepharose for immunoprecipitation on a rocking platform at $4^{\circ} \mathrm{C}$ for $1 \mathrm{hr}$. The Sepharose was then washed with $50 \mathrm{mM}$ Tris- $\mathrm{HCl}$ (pH 7.4), $0.05 \% \mathrm{NP}-40$, and the indicated concentration of $\mathrm{NaCl}$ (NET buffer). The coprecipitated RNAs were extracted and analyzed as described (Banroques and Abelson 1987).

For pre-mRNA coprecipitation studies, anti-PRP11 and preiummune antibodies were immobilized on protein A-Sepharose as described above except that the Sepharose was washed with either splicing buffer $\left(60 \mathrm{mM} \mathrm{KPO}\right.$ at $\mathrm{pH} 7,3 \mathrm{mM} \mathrm{MgCl}_{2}$, $3 \%$ PEG-8000, $8 \%$ glycerol, $1.5 \mathrm{mM}$ dithiothreitol) with $1 \mathrm{mg} /$ $\mathrm{ml}$ of ammonium heparin (Sigma), or NET with the indicated salt concentration. Twenty microliters of $40 \%$ (vol/vol) WCE in splicing buffer was first incubated for $10 \mathrm{~min}$ at $23^{\circ} \mathrm{C}$ to deplete the WCE of endogenous ATP. In some experiments, $2 \mathrm{~mm}$ glucose was added to the mixture to completely deplete the endogenous ATP (Horowitz and Abelson 1993). The splicing assay was initiated by adding 16 fmoles of pre-mRNA and 30 nmoles of ATP as indicated. The splicing reactions were quenched at $0^{\circ} \mathrm{C}$ with the addition of $1 \mu \mathrm{g} / \mu \mathrm{l}$ of ammonium heparin and then added to the immobilized antibody. After $1 \mathrm{hr}$ of incubation at $4^{\circ} \mathrm{C}$ on a rocking platform, the immunoprecipitates were washed with either splicing buffer or the appropriate NET. The coprecipitated RNAs were extracted and analyzed as described above and measured with a Molecular Dynamics PhosphorImager.

\section{Native gel electrophoresis}

A $10-\mu l$ splicing reaction with radiolabeled pre-mRNA was quenched by adding it to $10 \mu \mathrm{l}$ of ice-cold $50 \mathrm{mM}$ HEPES-K + (pH 7.4), $2 \mathrm{~mm}\left(\mathrm{CH}_{3} \mathrm{COO}\right)_{2} \mathrm{Mg}$ ( $\mathrm{R}$ buffer; Seraphin and Rosbash 1988) with $2 \mu \mathrm{g} / \mu \mathrm{l}$ of carrier RNA. Carrier RNA was prepared from mouse intestine as described (Auffray and Rougeon 1980). The sample was incubated on ice for $10 \mathrm{~min}$, and $5 \mu \mathrm{l}$ of loading buffer [200 mM Tris-phosphate $\left(\mathrm{pH} 8.0\right.$ at $0^{\circ} \mathrm{C}$ ), $50 \%$ (vol/vol) glycerol] was added. The samples were fractionated on a $3.2 \%$ polyacrylamide gel (50:1 acrylamide/bisacrylamide) in $48 \mathrm{~mm}$ Tris-phosphate (pH 8.0 at $\left.0^{\circ} \mathrm{C}\right), 1.5 \mathrm{~mm}\left(\mathrm{CH}_{3} \mathrm{COO}\right)_{2} \mathrm{Mg}$ (TPM8 buffer) at $4^{\circ} \mathrm{C}$ for $16-20 \mathrm{hr}$ at $5.5-6.7 \mathrm{~V} / \mathrm{cm}$. The gel was transferred to $3 \mathrm{MM}$ Whatman paper, and the complexes were visualized by autogradiography.

For assaying antibody inhibition of pre-spliceosome complex formation, antibody from anti-PRP11 or preimmune sera was prepared by affinity chromatography with protein A-Sepharose as described previously (Banroques and Abelson 1989). From 4 to $100 \mu \mathrm{g}$ of antibody was added to WCE and incubated on ice for $30 \mathrm{~min}$. Splicing buffer components, ATP and radiolabeled pre-mRNA were then added and the reactions were incubated for $20 \mathrm{~min}$ at $23^{\circ} \mathrm{C}$. The reactions were quenched at $0^{\circ} \mathrm{C}$ and analyzed by native gel electrophoresis.

\section{Acknowledgments}

We thank the following for communicating results prior to publication: A. Kramer, R. Brosi, H. Hauri, K. Groning, S. Behrens, and R. Luhrmann; M. Bennet and R. Reed; S. Fischer-Wells and M. Ares; P. Legrain, C. Chapon, and F. Gallison; J. Arenas; and C. O'Day. We thank the following for antibodies, plasmids, or yeast strains: J. Banroques, G. McFarland, K. Schappert, M. Ares, P. Legrain, B. Sikorski, M. Werner-Washburn, J. Beggs, A. Hopper, J. Woolford, U. Vijayraghavan, M. Company, and S. Scher. We thank M. Ares, S. Burgess, S. Fischer-Wells, C. Guthrie, C. Lesser, H. Madhani, E. Sontheimer, J. Steitz, J. Summers, and $M$. Werner-Washburn for comments on the manuscript. We thank P. Smith for technical assistance with some of these ex- 
periments. This work was supported by National Institutes of Health grant GM32637 (to J.A.) and by funds from University of New Mexico School of Medicine and Cancer Center (to S.R.).

The publication costs of this article were defrayed in part by payment of page charges. This article must therefore be hereby marked "advertisement" in accordance with 18 USC section 1734 solely to indicate this fact.

\section{References}

Abovich, N., P. Legrain, and M. Rosbash. 1990. The yeast PRP6 gene encodes a U4/U6 small nuclear ribonucleoprotein particle (snRNP) protein, and the $P R P 9$ gene encodes a protein required for U2 snRNP binding. Mol. Cell. Biol. 10: 64176425.

Adams, A.E.M. and D. Botstein. 1989. Dominant suppressors of yeast actin mutations are reciprocally suppressed. Genetics 121: 675-683.

Adams, A.E.M., D. Botstein, and D.G. Drubin. 1989. A yeast actin-binding protein is encoded by $S A C 6$, a gene found by suppression of an actin mutation. Science 243: 231-233.

Aebi, M., H. Hornig, and C. Weissmann. 1987. 5' cleavage site in eukaryotic pre-mRNA splicing is determined by the overall $5^{\prime}$ splice region, not by the conserved $5^{\prime}$ GU. Cell 50: $237-246$.

Arenas, J. and J. Abelson. 1993. The Saccharomyces cerevisiae PRP21 gene product is required for pre-spliceosome assembly. Proc. Natl. Acad. Sci. 90: 6771-6775.

Ares, M. and A.H. Igel. 1990. Lethal and temperature-sensitive mutations and their suppressors identify an essential structural element in U2 small nuclear RNA. Genes \& Dev. 4: 2132-2145.

Arndt, K.T., C.A. Styles, and G.R. Fink. 1989. A suppressor of a HIS4 transcriptional defect encodes a protein with homology to the catalytic subunit of protein phosphatases. Cell 56: $527-537$.

Auffray, C. and F. Rougeon. 1980. Purification of mouse immunoglobulin heavy-chain messenger RNAs from total myeloma tumor RNA. Eur. J. Biochem. 107: 303-324.

Bacon, R.A., A. Salminen, H. Ruohola, P. Novick, and S. FerroNovick. 1989. The GTP-binding protein Yptl is required for transport in vitro: The golgi apparatus is defective in ypt1 mutants. J. Cell Biol. 109: 1015-1022.

Baker, B.S. 1989. Sex in flies, the splice of life. Nature 340: 521524.

Banroques, J. and J.N. Abelson. 1989. PRP4: A protein of the yeast U4/U6 small nuclear ribonucleoprotein particle. Mol. Cell. Biol. 9: 3710-3719.

Behrens, S., K. Tyc, B. Kastner, J. Reichelt, and R. Luhrmann. 1993a. Small nuclear ribonucleoprotein (RNP) U2 contains numerous additional proteins and has a bipartite RNP structure under splicing conditions. Mol. Cell. Biol. 13:307-319.

Behrens, S-E., F. Galisson, P. Legrain, and R. Luhrmann. 1993b. Evidence that the $60-\mathrm{kDa}$ protein of $17 \mathrm{~S}$ U2 small nuclear ribonucleoprotein is immunologically and functionally related to the yeast PRP9 splicing factor and is required for the efficient formation of prespliceosomes. Proc. Natl. Acad. Sci., in press.

Bender, A. and J.R. Pringle. 1991. Use of a screen for synthetic lethal and multicopy suppressor mutants to identify two new genes involved in morphogenesis in Saccharomyces cerevisiae. Mol. Cell. Biol. 11: 1295-1305.

Bennett, M. and R. Reed. 1993. The essential spliceosome component SAP62 is a zinc finger protein similar to the yeast splicing factor PRP11 Science (in press).
Bindereif, A. and M. Green. 1987. An ordered pathway of snRNP binding during mammalian pre-mRNA splicing complex assembly. EMBO J. 6: 2415-2424.

Bjorn, S.P., A. Soltyk, J.D. Beggs, and J.D. Friesen. 1989. PRP4 (RNA4) from Saccharomyces cerevisiae: Its gene product is associated with the U4/U6 small nuclear ribonucleoprotein particle. Mol. Cell. Biol. 9: 3698-3709.

Brosi, R., H.P. Hauri, and A. Kramer. 1993a. Separation of splicing factor SF3 into two components and purification of SF3a activity. Biochemistry (in press).

Brosi, R., K. Groning, A. Kramer, S-E. Behrens, and R. Luhrmann. 1993b. Interaction of mammalian splicing factor SF3a with U2 snRNP and relationship of its $60-\mathrm{kDa}$ subunit to yeast PRP9. Science (in press).

Brow, D.A. and C. Guthrie. 1988. Spliceosomal RNA U6 is remarkably conserved from yeast to mammals. Nature 334: 213-218.

Brown, J.D., M. Plumptom, and J.D. Beggs. 1992. The genetics of nuclear pre-mRNA splicing: A complex story. Antonie Leeuwenhoek 62: 35-46.

Burgess, S., J.R. Couto, and C. Guthrie. 1990. A putative ATP binding protein influences the fidelity of branch point recognition in yeast splicing. Cell 60: 705-717.

Chang, T.-H., M.W. Clark, A.J. Lustig, M.E. Cusick, and J. Abelson. 1988. RNAll protein is associated with the yeast spliceosome and is localized in the periphery of the nucleus. Mol. Cell. Biol. 8: 2379-2393.

Chapon, C. and P. Legrain. 1992. A novel gene, spp91-1, suppresses the splicing defect and the pre-mRNA nuclear export in the prp9-1 mutant. EMBO /. 11: 3279-3288.

Cheng, S.-C. and J. Abelson. 1987. Spliceosome assembly in yeast. Genes \& Dev. 1: 1014-1027.

Christianson, T.W., R.S. Sikorski, M. Danter, J.H. Shero, and P. Hieter. 1992. Multifunctional yeast high-copy-number shuttle vectors. Gene 10: 119-122.

Dalbadie-McFarland, G. and J. Abelson. 1990. PRP5: A helicaselike protein required for mRNA splicing in yeast. Proc. Natl. Acad. Sci. 87: 4236-4240.

Datta, B. and A.M. Weiner. 1991. Genetic evidence for base pairing between $\mathrm{U} 2$ and U6 snRNA in mammalian mRNA splicing. Nature 352: 821-824.

Deshaies, R.J., S.L. Sanders, D.A. Feldheim, and R. Schekman. 1991. Assembly of yeast Sec proteins involved in translocation into the endoplasmic reticulum into a membranebound multisubunit complex. Nature 349: 806-808.

Frank, D., B. Patterson, and C. Guthrie. 1992. Synthetic lethal mutations suggest interactions between U5 small nucler RNA and four preins required for the second step of splicing. Mol. Cell. Biol. 12: 5197-5205.

Fu, X.-D. and T. Maniatis. 1992. General splicing factors SF2 and SC35 have equivalent activities in vitro and both affect alternative $5^{\prime}$ and $3^{\prime}$ splice site selection. Proc. Natl. Acad. Sci. 89: 11224-11228.

Ge, H., P. Zuo, and J.L. Manley. 1991. Primary structure of the human splicing factor ASF reveals similarities with Drosophila regulators. Cell 66: 373-382.

Green, M.R. 1991. Biochemical mechanisms of constitutive and regulated pre-mRNA splicing. Annu. Rev. Cell Biol. 7: 559599.

Guthrie, C. 1991. Messenger RNA splicing in yeast: Clues to why the spliceosome is a ribonucleoprotein. Science 253: $157-163$.

Guthrie, C. and G.R. Fink, eds. 1991. Guide to yeast genetics and molecular biology. Vol. 194. Academic Press, Inc., San Diego, CA.

Haffter, P., T.W. McMullin, and T.D. Fox. 1991. Functional in- 
teractions among two yeast mitochondiral ribosomal proteins and an mRNA-specific translational activator. Genetics 127: 319-326.

Hall, K.B. and M.M. Konarska. 1992. The $5^{\prime}$ splice site consensus RNA oligonucleotide induces assembly of $U 2 / U 4 / U 5 /$ U6 small nuclear ribonucleoprotein complexes. Proc. Natl. Acad. Sci. 89: 10969-10973.

Hausner, T.P., L.M. Giglio, and A.M. Weiner. 1990. Evidence for base-pairing between mammalian $\mathrm{U} 2$ and $\mathrm{U} 6$ small nuclear ribonucleoprotein particles. Genes \& Dev. 4: 2146-2156.

Hennessy, K.M., A. Lee, E. Chen, and D. Botstein. 1991. A group of interacting yeast DNA replication genes. Genes \& Dev. 5: 958-969.

Horowitz, D. and J. Abelson. 1993. Stages in the second reaction of pre-mRNA splicing: The final step is ATP independent. Genes \& Dev. 7: 320-329.

Huffaker, T., M.A. Hoyt, and D. Botstein. 1987. Genetic analysis of the yeast cytoskeleton. Annu. Rev. Genet. 21: 259284.

Ito, H., Y. Fukuda, K. Murata, and A. Kimura. 1983. Transformation of intact yeast cells treated with alkali cations. $I$. Bacteriol. 153: 163-168.

Jacquier, A. 1990. Self-splicing group II and nuclear pre-mRNA introns: How similar are they? Trends Biochem. Sci. 15: 351-354.

Jarvik, J. and D. Botstein. 1973. A genetic method for determining the order of events in a biological pathway. Proc. Natl. Acad. Sci. 70: 2046-2050.

Jones, J.S. and L. Prakash. 1990. Yeast Saccharomyces cerevisiae selectable markers in pUC18 polylinkers. Yeast 6: 363366.

Kim, S.-H. and R.-J. Lin. 1993. Pre-mRNA splicing within an assembled yeast spliceosome requires an RNA-dependent ATPase and ATP hydrolysis. Proc. Natl. Acad. Sci. 90: 888892.

King, D.S. and J.D. Beggs. 1990. Interactions of PRP2 protein with pre-mRNA splicing complexes in Saccharomyces cerevisiae. Nucleic Acids Res. 18: 6559-6564.

Konarska, M. 1988. Association of U2, U4, U5, and U6 small nuclear ribonucleoproteins in a spliceosome-type complex in absence of precursor RNA. Proc. Natl. Acad. Sci. 85: 5459-5462.

Krainer, A.R., A. Mayeda, D. Kozak, and G. Binns. 1991. Functional expression of cloned human splicing factor SF2: Homology to RNA binding proteins, U1 70K, and Drosophila splicing regulators. Cell 66: 383-394.

Kramer, A. and U. Utans. 1991. Three protein factors (SF1, SF3, and U2AF) function in pre-splicing complex formation in addition to snRNPs. EMBO I. 10: 1503-1509.

Lamond, A., M. Konarska, and P. Sharp. 1988. Spliceosome assembly involves binding and release of U4 small nuclear ribonucleoprotein. Proc. Natl. Acad. Sci. 85: 411-415.

Last, R.L., J.R. Maddock, and J.L. Woolford, Jr. 1987. Evidence for related functions of the RNA genes of Saccharomyces cerevisiae. Genetics 117: 619-631.

Lear, A.L., L.P. Eperon, I.M. Wheatley, and I.C. Eperon. 1990. Hierarchy for 5 ' splice preference determined in vivo. $1 . \mathrm{Mol}$. Biol. 211: 103-115.

Legrain, P. and C. Chapon. 1993. Identification of the yeast PRP9/PRP11/SPP91 splicing factor complex required for prespliceosome assembly. Science (in press).

Legrain, P. and A. Choulika. 1990. The molecular characterization of PRP6 and PRP9 yeast genes reveals a new cysteine/ histidine motif common to several splicing factors. $E M B O \mathrm{I}$. 9: 2775-2781.

Legrain, P., C. Chapon, E. Schwob, R. Martin, M. Rosbash, and
B. Dujon. 1991. Cloning of the two essential yeast genes, PRP6 and PRP9, and their rapid mapping, disruption and partial sequencing using a linker insertion strategy. Mol. Gen. Genet. 225: 199-202.

Legrain, P., C. Chapon, and F. Galisson. 1993. Interactions between PRP9 and SPP91 splicing factors indentify a protein complex required in prespliceosome assembly. Genes \& Dev. 7: 1390-1399.

Liao, X.C., H.V. Colot, Y. Wang, and M. Rosbash. 1992. Requirements for U2 snRNP addition to yeast pre-mRNA. Nucleic Acids Res. 20: 4237-4245.

Lin, R.J., A.J. Newman, S.-C. Cheng, and J. Abelson. 1985. Yeast mRNA splicing in vitro. I. Biol. Chem. 260: 14780-14792.

Lin, R.J., A.J. Lustig, and J.N. Abelson. 1987. Splicing of yeast nuclear pre-mRNA in vitro requires a functional $40 \mathrm{~S}$ spliceosome and several extrinsic factors. Genes \& Dev. 1: 7-18.

Linder, P. and A. Prat. 1990. Baker's yeast, the new work horse in protein synthesis studies: Analyzing eukryotic translation initiation. BioEssays 12: 519-526.

Lustig, A.J., R.J. Lin, and J. Abelson. 1986. The yeast RNA gene products are essential for mRNA splicing in vitro. Cell 47: 953-963.

Madhani, H.D. and C. Guthrie. 1992. A novel base-pairing interaction between U2 and U6 snRNAs suggests a mechanism for the catalytic activation of the spliceosome. Cell 71: 803-817.

McPheeters, D.S. and J. Abelson. 1992. Mutational analysis of the yeast U2 snRNA suggests a structural similarity to the catalytic core of Group I introns. Cell 171: 819-831.

Miraglia, L., S. Seiwert, A.H. Igel, and M. Ares. 1991. Limited functional equivalence of phylogenetic variation in small nuclear RNA: Yeast U2 RNA with altered branch point complementarity inhibits splicing and produces a dominant lethal phenotype. Proc. Natl. Acad. Sci. 88: 7061-7065.

Moore, M.J., C.C. Query, and P.A. Sharp. 1993. Splicing of precursors to mRNAs by the spliceosome. In The RNA world (ed. R.F. Gesteland and J.F. Atkins), pp. 303-358. Cold Spring Harbor Laboratory Press, Cold Spring Harbor, New York.

Newman, A.J. and C. Norman. 1992. U5 snRNA interacts with exon sequences at $5^{\prime}$ and $3^{\prime}$ splice sites. Cell 68: 743-754.

Novick, P., B.C. Osmond, and D. Botstein. 1989. Suppressors of yeast actin mutations. Genetics 121: 659-674.

Parker, R., P.G. Siliciano, and C. Guthrie. 1987. Recognition of the TACTAAC box during mRNA splicing in yeast involves base pairing to the U2-like snRNA. Cell 49: 229-239

Pause, A. and N. Sonenberg. 1992. Mutational analysis of a DEAD box RNA helicase: The mammalian translation initiation factor eIF4A. EMBO J. 11: 2643-2654.

Ray, B.K., T.G. Lawson, J.C. Kramer, M.H. Cladaras, J.A. Grifo, R.D. Abramson, W.C. Merrich, and R.E. Thach. 1985. ATPdependent unwinding of messenger RNA capbinding proteins mediated by eukaryotic initiation factor 4B. $J$. Biol. Chem. 260: 7651-7658.

Reich, C.I., R.W. VanHoy, G.L. Porter, and J.A. Wise. 1992. Mutations at the 3 ' splice site can be suppressed by compensatory base changes in U1 snRNA in fission yeast. Cell 69: 120.

Rosbash, M. and B. Seraphin. 1991. Who's on first? the U1 snRNP-5' splice site interaction and splicing. Trends Biochem. 16: $187-190$.

Rossi, G., Y. Jiang, and A.P. Newman. 1991. Dependence of Ypt1 and Sec4 membrane attachment on Bet2. Nature 351: 158-161.

Rothblatt, J.A., R.J. Deshaies, S.L. Sanders, G. Daum, and R. Schekman. 1989. Multiple genes are required for proper insertion of secretory proteins into the endoplasmic reticulum 
in yeast. J. Cell Biol. 109: 2641-2652.

Rozen, F., I. Edery, K. Meerovitch, T.E. Dever, W.C. Merrick, and N. Sonenberg. 1990. Bidirectional RNA helicase activity of eucaryotic translation initiation factors 4A and 4F. Mol. Cell. Biol. 10: 1134-1144.

Ruby, S.W. and J. Abelson. 1988. An early hierachic role of U1 small nuclear ribonucleoprotein in spliceosome assembly. Science 242: 1028-1035. 85.

Rymond, B.C. and M. Rosbash. 1992. Yeast pre-mRNA splicing. In The molecular and cellular biology of the yeast Saccharomyces (ed. E.W. Jones, J.R. Pringle, and J.R. Broach), vol. 2, pp. 143-192. Cold Spring Harbor Laboratory Press, Cold Spring Harbor, New York.

Salminen, A. and P.J. Novick. 1987. A ras-like protein is required for a post-golgi event in yeast secretion. Cell 49: 527538.

- 1989. The Sec15 protein responds to the function of the GTP binding protein, Sec4, to control vesicular traffic in yeast. J. Cell Biol. 109: 1023-1036.

Sawa, H. and J. Abelson. 1992. Evidence for a base-pairing interaction between U6 small nuclear RNA and the $5^{\prime}$ splice site during the splicing reaction in yeast. Proc. Natl. Acad. Sci. 89: 11269-11273.

Schappert, K. and J.D. Friesen. 1991. Genetic studies of the PRP11 gene of Saccharomyces cerevisiae. Mol. Gen. Genet. 226: 277-282.

Schmid, S.R. and P. Linder. 1992. D-E-A-D protein family of putative RNA helicases. Mol. Microbiol. 6: 283-292.

Schwer, B. and C. Guthrie. 1991. PRP16 is an RNA-dependent ATPase that interacts transiently with the spliceosome. $\mathrm{Na}$ ture 349: 494-499.

Seraphin, B. and M. Rosbash. 1989. Identification of functional U1 sn-RNA-pre-mRNA complexes committed to spliceosome assembly and splicing. Cell 59: 349-358.

Shannon, K.W. and C. Guthrie. 1993. Suppressors of a U4 snRNA mutation define a novel U6 snRNP protein with RNA-binding motifs. Genes \& Dev. 5: 773-785.

Sonenberg, N. 1988. Cap-binding proteins of eukaryotic messenger RNA: Functions in inititation and control of translation. Progr. Nucleic Acids Res. 35: 173-207.

Stearns, T., M.A. Hoyt, and D. Botstein. 1990. Yeast mutants sensitive to antimicrotubule function. Genetics 124: 251262.

Tian, M. and T. Maniatis. 1992. Positive control of pre-mRNA splicing in vitro. Science 256: 237-240.

Vijayraghavan, U., R. Parker, J. Tamm, J. Rossi, J. Abelson, and C. Guthrie. 1986. Mutations in conserved intron sequences affect multiple steps in the yeast splicing pathways, particularly assembly of the spliceosome. EMBO J. 7: 1683-1695.

Vijayraghavan, U., M. Company, and J. Abelson. 1989. Isolation and characterization of prem-RNA splicing mutants of Saccharomyces cerevisiae. Genes \& Dev. 3: 1206-1216.

Wassarman, D. and J. Steitz. 1991. Alive with DEAD proteins. Nature 349: 463-464.

1992. Interactions of small nuclear RNAs with precursor messenger RNA during in vitro splicing. Science 257: 1918-1925.

Weiner, A.M. 1993. mRNA splicing and autocatalytic introns: Distant cousins or the products of chemical determinism? Cell 72: 161-164.

Wu, J. and J.L. Manley. 1991. Base pairing between U2 and U6 snRNAs is necessary for splicing of a mammalian premRNA. Nature 352: 818-821.

Wyatt, J.R., E.J. Sontheimer, and J. Steitz. 1992 Site-specific cross-linking of mammalian U5 snRNP to the $5^{\prime}$ splice site before the first step of pre-mRNA splicing. Genes \& Dev. 6: 2542-2553.

Zamore, P.D. and M.R. Green. 1989. Identification, purification, and biochemical characterization of U2 small nuclear ribonucleoprotein auxiliary factor. Proc. Natl. Acad. Sci. 86: 9243-9249.

Zavanelli, M.I. and M. Ares. 1991. Efficient association of U2 snRNPs with pre-mRNA requires an essential U2 RNA structural element. Genes \& Dev. 5: 2521-2533.

Zhuang, Y. and A.M. Weiner. 1989. A compensatory base change in human U2 snRNA can suppress a branch site mutation. Genes \& Dev. 3: 1545-1552. 


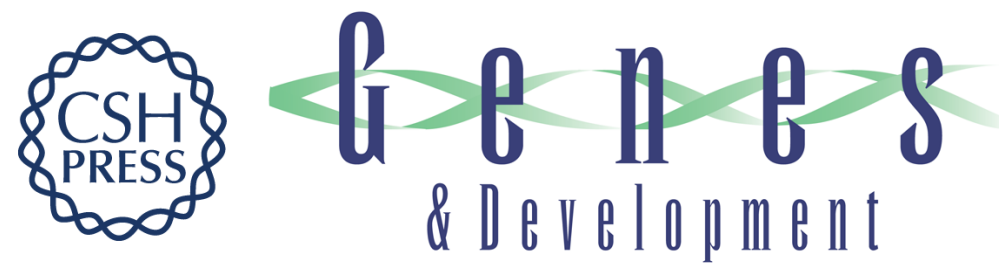

\section{Four yeast spliceosomal proteins (PRP5, PRP9, PRP11, and PRP21) interact to promote U2 snRNP binding to pre-mRNA.}

S W Ruby, TH Chang and J Abelson

Genes Dev. 1993, 7:

Access the most recent version at doi:10.1101/gad.7.10.1909

References This article cites 92 articles, 45 of which can be accessed free at:

http://genesdev.cshlp.org/content/7/10/1909.full.html\#ref-list-1

License

Email Alerting

Service

Receive free email alerts when new articles cite this article - sign up in the box at the top right corner of the article or click here.

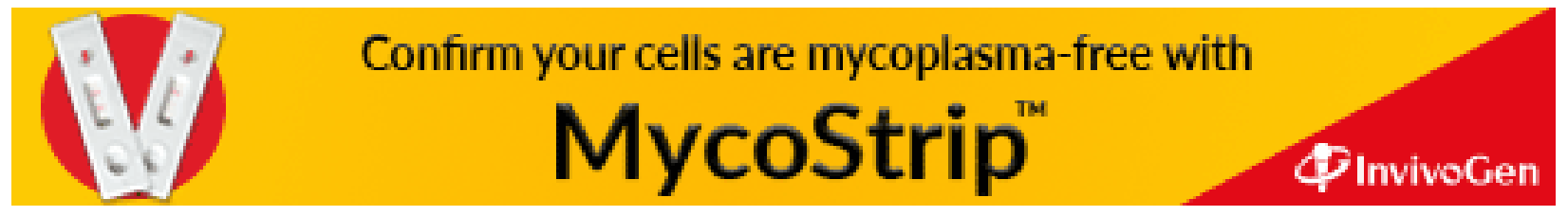

